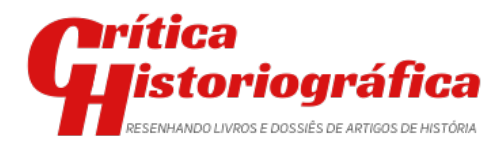

Crítica Historiográfica. Natal, v.2, n.3, jan./fev. 2022 | 2764-2666

Publicação: 2021-12-30

\section{Corpo editorial}

\section{Editor-chefe}

- Profa. Dra. Margarida Maria Dias de Oliveira (UFRN)

- Universidade Federal do Rio Grande do Norte, UFRN-Campus Central, BR 101, Lagoa nova. CEP 59078-970, Natal-RN. Cel.: 84991641675 E-mail margaridahistoria@yahoo.com.br

\section{Autores corporativos}

- Grupo de pesquisa "Espaços, poder, práticas sociais" da Universidade Federal do Rio Grande do Norte. Campus Universitário Lagoa Nova | Caixa Postal 1524 | CEP 59078-900 | Natal/RN - Brasil

- CNPq: http://dgp.cnpq.br/dgp/espelhogrupo/595907.

- E-mail: eppsgrupo@gmail.com

- Facebook Espaços, Poder e Práticas Sociais

- Instagram: @eppsgrupo

- Youtube: https://www.youtube.com/channel/UCNB9v2gy5CCHwstVdNdg-A

- Grupo de pesquisa "Aprendizagem histórica em espaços escolares e não escolares". Cidade Universitária Prof. José Aloísio de Campos. Bloco Departamental I, sala 9, Av. Marechal Rondon, S/N - Rosa Elze, 49100000 São Cristóvão - SE

- CNPq: dgp.cnpq.br/dgp/espelhogrupo/3087460812169010.

\section{Editor-executivo}

- Prof. Dr. Itamar Freitas (UFS)

\section{Vice editores}

- Prof. Dr. Magno Francisco de Jesus Santos (UFRN)

- Prof. Dr. Fábio Alves dos Santos (UFS)

\section{Comissão editorial}

- Prof. Dr. Almir Félix Batista de Oliveira (UFRN)

- Prof. Dr. André Cabral Honor (UnB)

- Prof. Dr. Arnaldo Martin Szlachta Junior (UFPE)

- Prof. Dr. Bruno Balbino Aires da Costa (IFRN)

- Profa. Dra. Carmem Zeli Gil (UFRGS)1 
- Prof. Dr. Dilton Cândido Maynard (UFRJ/UFS)

- Prof. Dr. Eduardo Henrique Barbosas de Vasconcelos (UEG)

- Prof. Dr. Erinaldo Vicente Cavalcanti (UNIFESPA)

- Profa. Dra. Fabíula Sevilha de Souza (UFRN)

- Prof. Dr. Francisco Egberto de Melo (URCA)

- Profa. Dra. Flavia Eloisa Caimi (UPF)

- Prof. Dr. Hermeson Alves de Menezes (UAB/UFS)

- Profa. Dra. Jane Derarovele Semeão (URCA)

- Prof. Dr. João Mauricio Gomes Ribeiro (UNIR)

- Profa. Dra. Joceneide Santos Cunha (UNEB)

- Prof. Dr. José Vieira da Cruz (UFS)

- Profa. Dra. Juliana Teixeira Souza (UFRN)

- Prof. Dr. Jucieldo Ferreira Alexandre (UFCA)

- Prof. Dr. Lucas Pinheiro (UFS)

- Prof. Dr. Lucas Victor Silva (UFRPE)

- Dra. Maria Augusta Castilho (UCDB)

- Profa. Dra. Maria de Lourdes Mônaco Janotti (USP)

- Profa. Dra. Maria Fernanda Batista Bicalho (UFF)

- Profa. Dra. Marieta de Moraes Ferreira (UFRJ)

- Profa. Dra. Marta Margarida Andrade Lima (UFRPE)

- Prof. Dr. Mauro Cézar Coelho (UFPA)

- Dra. Mônica Martins da Silva (UFSC)

- Prof. Dr. Péricles Andrade (UFS)

- Prof. Dr. Renilson Rosa Ribeiro (UFMT)

- Prof. Dr. Robson Wiliam Potier (SEEC/RN)

- Profa. Dra. Rosa Maria Godoy Silveira (UFPB)

- Profa. Dra. Rosiane da Silva Ribeiro Bechler (UFVJM)

- Profa. Dra. Sandra Regina Ferreira Oliveira (UEL/PR)

- Profa. Dra. Sonia Menezes (URCA)

- Prof. Dr. Tiago Santos Almeida (UFGO)

- Profa. Dra. Vanessa Spinosa (UFRN)

- Prof. Dr. Wesley Garcia Ribeiro Silva (UFPA)

- Profa. Dra. Wilma de Nazaré Baia Coelho (UFPA)

\section{Apoio técnico}

- Antonio Marcos Pinto Coelho (PlanPlen Web Marketing)

- Maria Luiza Dantas Lins (UFRN)

- Rebeca Nadine de Araújo Paiva (UFRN) 


\section{Descolonizando a bibliografia - resenha de "Ensino de} História: fundamentos e métodos", de Circe Maria Fernandes Bittencourt

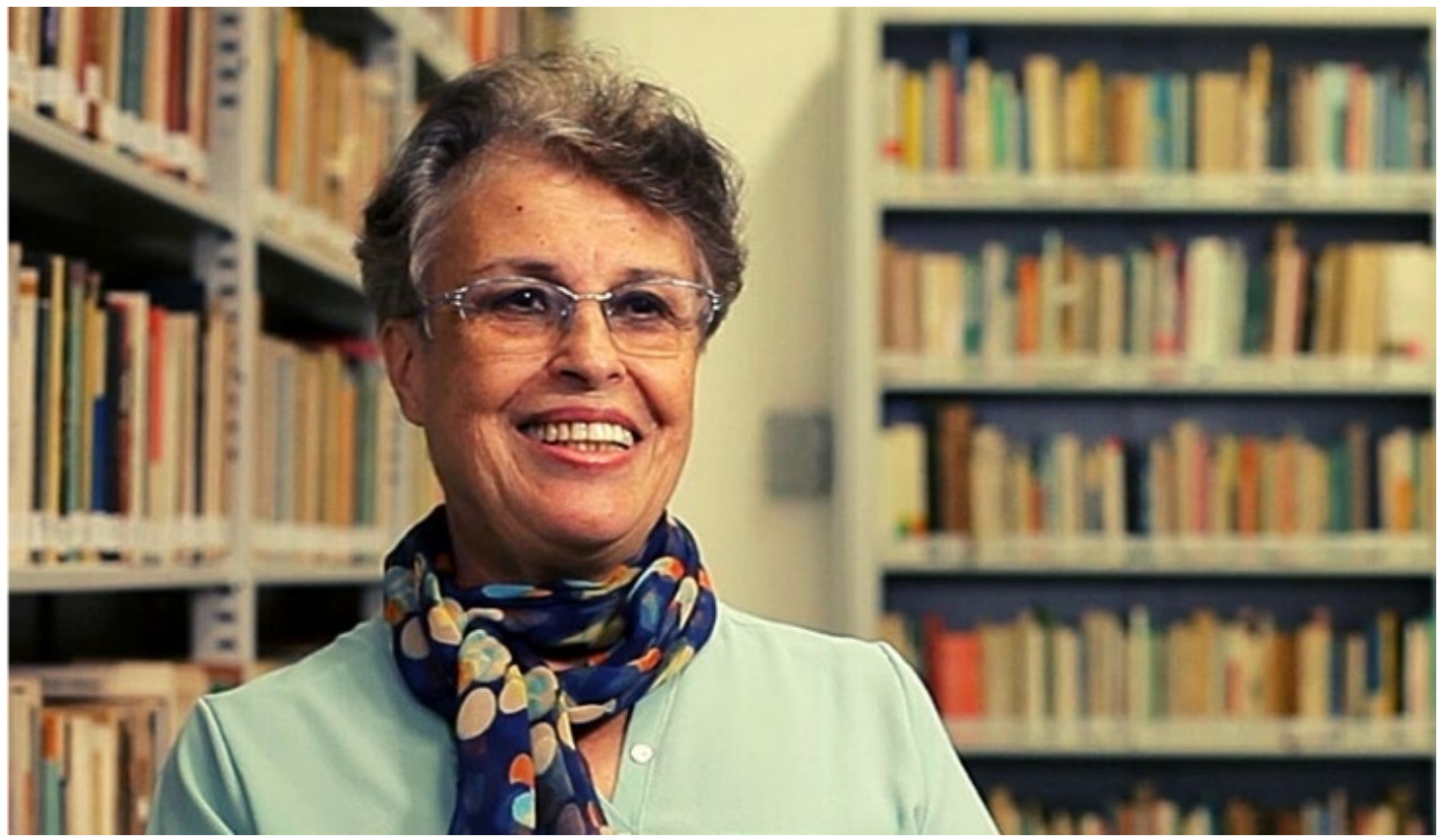

BM Comunicação

Ensino de História: fundamentos e métodos, escrito por Circe Bittencourt, é um livro que trata da atividade docente no Ensino Fundamental sob os pontos de vista histórico, epistemológico e metodológico (História e Pedagogia). Sua quinta edição foi lançada em 2018 e conserva o mesmo objetivo de 2004: subsidiar a formação inicial e continuada dos professores da escolarização básica e dos docentes do ensino superior, formadores dos futuros licenciados em História. 


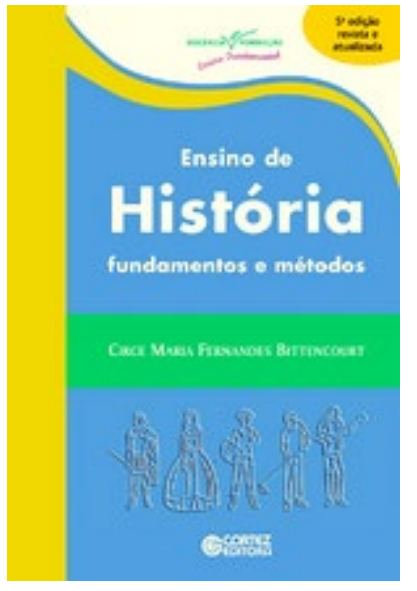

O livro faz sucesso desde a primeira edição. No site Resenha Crítica, a avaliação da obra é o post mais consultado neste ano de 2021, entre os, aproximadamente, 6.000 disponíveis (resenhas e apresentações de dossiês de artigo). São, em média, 50 acessos semanais (Bueno; Urban, 2019). No Google Acadêmico, a quinta edição já ultrapassou a marca das 2000 citações. É uma pena que depois de tantos ganhos empresariais, políticos e acadêmicos, essa versão, publicada em 2018, venha a público com as mesmas imperfeições detectadas há mais de uma década.

Para a nossa sorte, Bittencourt revelou as partes mais frágeis da obra, em entrevista recente a Diogo Roiz: a insuficiente discussão sobre a experiência do ensino de História nos anos iniciais do ensino fundamental, a ênfase na defesa da história temática como alternativa e, consequentemente, o abandono das outras variáveis de conteúdo substantivo (Bittencourt, 2020, p.20-22).

Bittencourt também explicitou o contexto de produção. Tratava-se, em 2004, de uma demanda editorial da Editora Cortez, interessada no alinhamento das publicações do gênero com a nova Lei de Diretrizes e Bases da Educação Nacional (1996). "A obra teve como eixo o Programa do curso de Metodologia de Ensino de História na FEUSP, acrescido de questões relativas ao ensino de História para as séries iniciais" (Bittencourt, 2020, p.21).

As insuficiências confessadas, porém, não foram comunicadas na segunda, terceira, quarta e quinta edições. O ideal seria apor uma apresentação a cada edição lançada, informando sobre eventuais mudanças de rotas nos domínios do Ensino de História nesse país.

São poucos e pontuais reparos. Na parte 1 (capítulo 2), o texto merece algumas linhas que informem sobre o avanço da pesquisa no tema. Desde 2009, o número de teses e dissertações, artigos, comunicações e de livros do tipo coletânea já deve ter ultrapassado a casa das centenas. Algumas dessas peças já destronaram, direta ou indiretamente, as teses da invenção do domínio supostamente ocorrida nos anos 80 do século passado e a predominância da experiência de Rio de Janeiro e de São Paulo como conteúdo substantivo para uma história do ensino de História no Brasil.

O capítulo três demonstra e comprova esse equívoco. Tratando de história nas "atuais propostas curriculares", a autora reviu as referências aos anos 1980, inseriu qualificativos e blocos de texto, acrescentando alguns parágrafos sobre os debates em torno da Base Nacional Comum Curricular - BNCC e do projeto "Escola sem Partido" e os desdobramentos da BNCC no Ensino Médio. A autora também redigiu um tópico inteiramente dedicado à inclusão da temática "diversidade social e cultural" nos currículos. Qual a razão do tratamento diferenciado? Haveria interesse políticoacadêmico em manter a tese-fundamento e interesse comercial em alterar a informação curricular?

No início da segunda parte, há conservação de posição fortemente contestada nos estudos que mapeiam e delimitam a pesquisa sobre ensino de História como domínio acadêmico. A autora afirma que "Ponto básico para o estabelecimento de um critério para a seleção de conteúdos é a concepção de história" (p.125). Pensamos ser necessário acrescentar (antes ou depois do tópico) a seguinte contextualização: "sob a perspectiva de formados em história que nunca experimentaram a educação básica”, a concepção de 
história é o ponto básico. Pensamos (inclusive com o apoio de um dos principais aportes empregados pela própria autora - André Chervel) que o "ponto básico" são as finalidades do ensino de História. Quem as prescreve: o professor, o Estado, o Mercado ou a família? E quando os fins já pressupõem uma filosofia especulativa da história e uma epistemologia da História, que deve fazer o professor com essas prescrições?

Coerente com a sua perspectiva, a autora expõe "algumas das tendências historiográficas" relacionadas à "produção escolar" (narrativa, econômica, social, cultural e do tempo presente). Ela declara que a "história narrativa" está associada a Ranke, que "passou a ser denominada de historicismo", gerando uma "metodologia conhecida como positivista", cujos praticantes "dedicaram-se ao estudo da individualidade irreproduzível e única, destacando figuras das elites e suas biografias" etc. Assim, um mesmo personagem e uma rubrica condensam todos os supostos males presentes no ensino de História, no passado e no presente, nos estados alemães e nos rincões do Brasil, sem distinção: ênfase no político, individualismo, elitismo, neutralidade e na objetividade. Essa posição (embora não tenha sido inventada por Bittencourt) é ruim para a formação do professor. Ela não dá a conhecer criticamente a história da historiografia e fornece um (falso) caminho para os que querem identificar o princípio do mal ensino sem nenhum esforço cognitivo e ético.

A eleição do "ponto básico" provoca imprecisão no capítulo seguinte. Se o princípio orientador "é a concepção de história", por que os historiadores de ofício não contribuem com ideias sobre aprendizagem histórica? Estaria a autora a sugerir que os historiadores entram com o conteúdo substantivo, e os psicólogos, com a teoria da aprendizagem?

No capítulo terceiro, o problema é de definição. A autora não informa o seu entendimento sobre "método", embora empregue, de modo categórico, as expressões "métodos tradicionais" e "métodos conservadores". Pensamos que todo "tradicional" é cunhado dentro de uma dada situação comunicativa. Ele é definido em meio à formação inicial do professor, à demanda imediata da escola, ao recurso material no interior da sala de aula e, principalmente, aos fins prescritos ou implícitos do componente curricular história em determinado contexto. Esse princípio torna sem efeito a caracterização do tradicional como o autoritário, o expositivo, o narrativo e o político. Quantos de nós sobrariam em sala de aula, caso tal classificação fosse transformada em lei? Deveríamos, então, concluir que - considerando do contexto majoritário de trabalho dos docentes da educação básica - elementos desse tradicional são, ao fim e ao cabo, em determinadas situações, virtudes do profissional contemporâneo?

Esse problema conceitual se repete na parte três, quando a autora trata do livro didático como "um objeto cultural complexo". O problema aqui é a recusa em definir. Livro didático (qualquer outro objeto) não é coisa de "difícil definição". Basta eleger os critérios - é o que a autora faz em seguida, implicitamente, ao citar a "familiaridade do uso". Logo depois, infelizmente, volta à carga da dificuldade, apresentando diferentes formas pelas quais o artefato pode ser abordado em sala de aula e fora dela: "produto cultural", "suporte de conhecimentos", "suporte de métodos pedagógicos", "veículo de um sistema de valores" etc. (p.301-302).

No capítulo segundo, da parte três, apresentamos uma divergência de princípio. A autora reproduz a frase do senso comum de que o professor não pode usar os documentos em sala de aula para formar um "pequeno historiador". Justifica a tese com a diferenciação de fins de uso (para o aluno da educação básica e para o professor). Isso é um equívoco. Os fins de uso, refletidos com base em princípios, são idênticos. Ao 
empregar procedimentos de crítica documental, um historiador e um aluno dos anos iniciais do Ensino Fundamental estão mobilizando/desenvolvendo/conservando/ampliando habilidades mentais reunidas na expressão que atravessa diferentes concepções de aprendizagem histórica: "pensar historicamente". Para a sorte da boa formação, a autora se contradiz na página seguinte ao sugerir os procedimentos empregados por Adalberto Marson (p.301-302).

No último capítulo do livro, a ausência de princípio historiador também é a ponta solta. Defendemos que professores de história não devem copiar acriticamente os procedimentos dos especialistas, por exemplo, da cultura material e da cultura do audiovisual. Nós progredimos pouco no ensino de História quando importamos procedimentos sem convicção de princípios da ciência histórica adequados à formação de pessoas. O fazer do museólogo e do cineasta, por exemplo, para representar o passado de nada vale se não estiver enquadrado em um princípio básico (também, por exemplo) do século XIX: deve-se afirmar sobre o passado apenas a partir de fontes criticadas por meios abonados em uma comunidade historiadora. Com isso, queremos reiterar que o ensino de História não pode ser uma coleção de metodologias de Educação Patrimonial, da Análise de Filmes ou das práticas de Musealização, alienada, por exemplo, do princípio de que a declaração historiadora deve ser apoiada em evidências refutáveis.

Uma apreciação da obra, tal qual fizemos aqui, não é um convite a excluí-la das bibliografias especializadas. Trata-se de uma iniciativa de redução de danos, efetuada por pessoas que leem e conhecem e (o mais importante) manifestam publicamente o seu amor ao saber de referência e de atuação. Estamos convictos de que as escolhas dos alunos são mediadas por sentimentos vários. Se são apaixonados por Fundamentos e Métodos, como somos apaixonados pela Ideologia alemã, de Karl Marx, por exemplo, se fazem todo o esforço para citá-lo até onde não há necessidade ou onde poderiam empregar bibliografia mais substantiva e atualizada, devemos contribuir para que essa ferramenta seja aperfeiçoada. Essa é a nossa intenção.

Se os editores quiserem também manifestar o seu amor ao saber, sem diminuir um centavo nos lucros auferidos com as vendas, certamente providenciarão um prefácio ou um posfácio para iminente sexta edição, fornecendo bibliografia atualizada em forma de apêndices, alertando aos leitores antigos e novos sobre as passagens datadas e as passagens modificadas dessa obra monumental e anexando a autocrítica da autora, publicada recentemente.

\section{Referências}

BITTENCOURT, Circe Maria Fernandes. Ensino de História: fundamentos e métodos. 5ed. São Paulo: Cortez, 2018. Resenha de: BUENO, Dioury de Andrade; URBAN, Ana Claudia. Revista de Educação Histórica, Curitiba, n. 19, p.83-87, jul./dez., 2019. Link

ROIZ, Diogo da Silva. Entrevista com Circe Bittencourt. Educação: Teoria e Prática. Rio Claro, v.30, n.63, p.1-25, jun. 2020. Link 


\section{Sumário de Ensino de História: fundamentos e métodos}

- Introdução

- Parte I. História escolar: perfil de uma disciplina

- O que é disciplina escolar?

- Conteúdos e métodos do Ensino de História: breve abordagem histórica

- História nas atuais propostas curriculares

- Parte II. Métodos e conteúdos escolares: uma relação necessária

○ Conteúdos históricos: como selecionar?

- Aprendizagens em História

- Procedimentos metodológicos no Ensino de História

- Procedimentos metodológicos em práticas interdisciplinares

- Parte III. Materiais didáticos: concepções e usos

- Livros e materiais didáticos de História

- Usos didáticos de documentos

- Documentos não escritos na sala de aula

\section{Resenhistas}

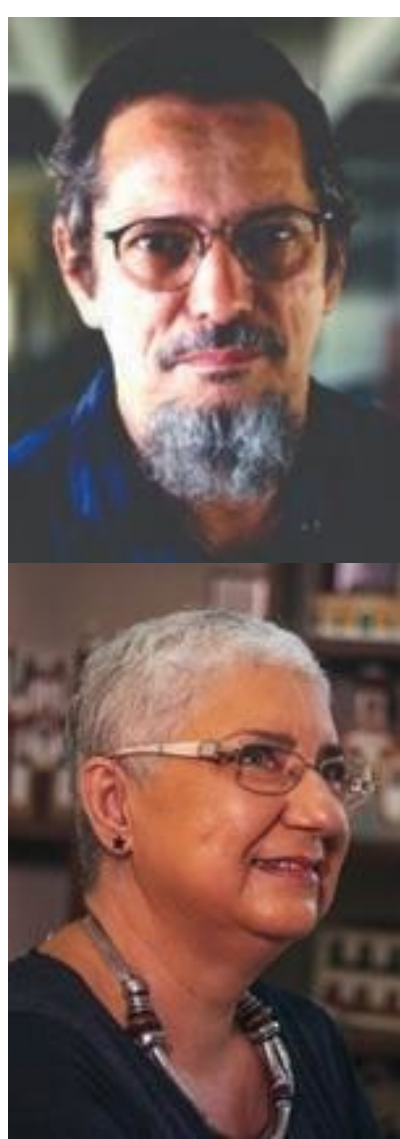

Itamar Freitas - Doutor em História (UFRGS) e em Educação (PUC-SP), Professor do Departamento de Educação e do Mestrado Profissional em História, da Universidade Federal de Sergipe, e editor do blog Resenha Crítica. Publicou, entre outros trabalhos, Uma introdução ao método histórico (2021) e "Objetividade histórica no Manual de Teoria da História de Roberto Piragibe da Fonseca (19031986)”.Email: itamarfreitas@gmail.com.

Margarida Maria Dias de Oliveira - Doutora em História pela Universidade Federal de Pernambuco (UFPE), Professora do Departamento e do Programa de Pós-Graduação em História da UFRN. Publicou, entre outros trabalhos, Dicionário do Ensino de História (2020), em coautoria com Marieta e Morais Ferreira, e Formação dos professores de História: os desafios de uma profissão em processo de reinvenção. Email: margaridahistoria@yahoo.com.br. 


\section{Para citar esta resenha}

BITTENCOURT, Circe Maria Fernandes. Ensino de História: fundamentos e métodos 5 ed. São Paulo: Cortez: 2018. 354p. E-book. Descolonizando a bibliografia. Resenha de: FREITAS, Itamar; OLIVEIRA, Margarida Maria Dias de. Crítica Historiográfica. Natal, v.2, n.3, jan./fev. 2021. Disponível em: https://www.criticahistoriografica.com.br/1858/

Baixar esta resenha em PDF

Consultar outras resenhas sobre Ensino de História: fundamentos e métodos

Dioury de Andrade Bueno e Ana Claudia Urban - Revista de Educação Histórica (2019)

(C) - Os autores que publicam em Crítica Historiográfica concordam com a distribuição, remixagem, adaptação e criação a partir dos seus textos, mesmo para fins comerciais, desde que lhe sejam garantidos os devidos créditos pelas criações originais. (CC BY$\mathrm{SA})$ 


\section{Stitues \\ 7 istoriográfica}

\section{Sobre concepções e empregos da História e da Filosofia das Ciências - resenha de "Cómo hacer cosas con Foucault. Instrucciones de uso" e a "Canguilhem. Vitalismo y Ciencias Humanas", de Francisco Vázquez García}

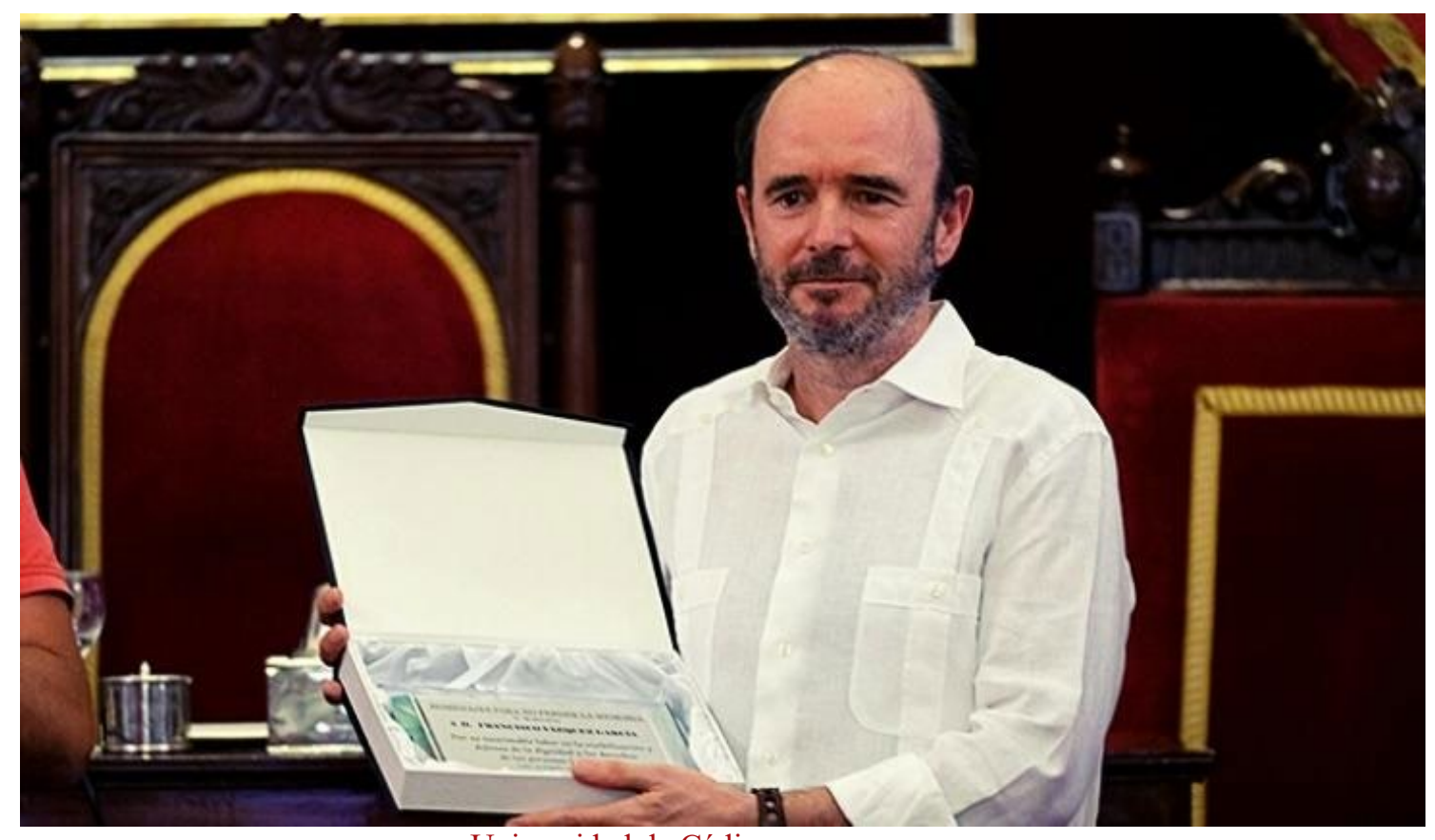

Universidad de Cádiz

Após a publicação, em 1987, do livro Estudios de historia de las ideas. Vol. 1, Locke, Hume e Canguilhem, escrito em coautoria com Ángel Manuel Lorenzo e José, L.

Tasset, Georges Canguilhem (1904 - 1995) enviou a seguinte mensagem ao historiador espanhol Francisco Vázquez García: "Sua análise dos meus estudos de epistemologia me diz que você me leu com atenção e simpatia (...). Eu constatei com satisfação que você percebeu bem aquilo que meus trabalhos devem aos trabalhos, bem mais prestigiosos, de Bachelard e de Koyré. Não posso abandonar as lições que tirei dessas leituras." (García, 2015). A seção do livro dedicada ao historiador francês recuperava o texto da monografia de licenciatura de Francisco, defendida três anos antes, na Universidad de Sevilla, sob o título La teoria de la historia de las ciencias de G. Canguilhem. Mais de trinta anos depois, García segue capaz de dizer coisas originais sobre a obra de Canguilhem - Georges Canguilhem: Vitalismo y Ciencias Humanas (2019) - e didatizar os usos da arqueo-genealogia de Foucault - Cómo hacer cosas con Foucault. Instrucciones de uso (2018), textos sobre os quais nos debruçamos a partir de agora. 


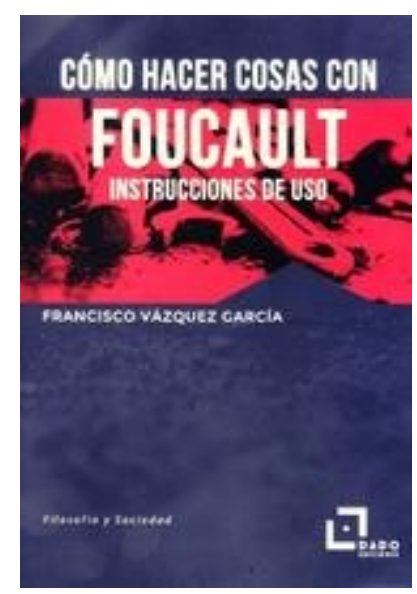

Francisco Vázquez García é especialista em história cultural da sexualidade e em sociologia da filosofia contemporânea francesa e espanhola, professor de filosofia na Universidad de Cádiz (UCA) e presidente da Asociación Centro

Iberoamericano de Estudios sobre Sexualidad. Ele é autor de dezenas de livros e artigos que mobilizam as metodologias histórico-epistemológica de Canguilhem e arqueo-genealógica de Michel Foucault para a abordagem de temas como a biopolítica, o racismo, a homossexualidade, o hermafroditismo e a identidade sexual do ponto de vista da história dos saberes médico e "psi". Também é autor de livros em história da historiografia, como os Estudios de teoría y metodología del saber histórico: De la escuela historica alemana al grupo de los "Annales" e Foucault. La historia como crítica de la razón, ambos publicados pela editora da UCA. Seus últimos dois livros dedicados aos filósofos-historiadores franceses testemunham a competência de Francisco em todas aquelas áreas, ao mesmo tempo que comprovam o interesse e a atualidade das obras de Foucault e Canguilhem para a história da historiografia e para a teoria da história. Além disso, de modo não intencional, mas nem por isso desimportante, possuem interesse para o campo da Saúde Coletiva brasileira, notadamente em seu componente "Ciências Sociais e Humanas em Saúde".

Em Cómo hacer cosas con Foucault. Instrucciones de uso, García orienta os usos práticos de categorias foucaultianas. Com uma introdução que reflete sobre "o que significa usar Foucault" e três capítulos que abordam, respectivamente, a "história do presente", a "análise dos discursos" (ou arqueologia) e a "análise das relações de poder" (ou genealogia), o livro expõe, por meio de exemplos retirados da própria experiência de pesquisa do autor, a utilização dessa "caixa de ferramentas" como uma técnica de análise sócio-histórica que permite explorar os discursos, as relações de poder e as práticas de si. É um livro propedêutico de grande utilidade formativa, cuja primeira atividade de lançamento foi realizada no Brasil, no Instituto de Saúde Coletiva da UFBA, e isso não é circunstancial.

O interesse desse campo de conhecimentos e práticas em saúde pela obra de Foucault acompanhou o processo de construção das suas bases epistemológica ao longo da década de 70, notadamente após a série de conferências ministradas por Foucault, em 1974, no Instituto de Medicina Social da UERJ (Naissance de la clinique, de 1963, também já circulava bastante no campo da Saúde no Brasil, inclusive a partir da tradução argentina, publicada pela Siglo XXI em 1966). De fato, os vários tipos de uso da obra de Foucault - como o programático, o poiético-praxeológico ou o segmentário, catalogados e classificados por Francisco a partir de uma ampla história intelectual da recepção do autor de $O$ nascimento da clínica em diferentes contextos podem ser identificados tanto nas historiografias feminista, decolonial ou LGBTQIA+, exemplos abordados em Cómo hacer cosas con Foucault, como nos debates que se desenvolveram nessas mais de quatro décadas da Saúde Coletiva brasileira, campo ao qual o autor, de fato, não se dedica, embora permita verdadeiros insights.

O segundo livro do mesmo autor, Georges Canguilhem. Vitalismo y Ciencias Humanas explica por que Francisco permanece, após tantos anos, na lista dos principais comentadores, ao mesmo tempo sendo reconhecido como um dos impulsionadores do movimento recente de redescoberta do autor de $O$ normal e o patológico pelos historiadores. Não houve lançamento no Brasil, mas um dos seus capítulos mais interessantes foi inicialmente apresentado como conferência no colóquio "Canguilhem, 
a história e os historiadores", realizado no Departamento de História da USP, em 2015. Em "Canguilhem, la Historia e la Geografia. El encuentro con la escuela de los Annales", podemos dizer que Francisco realiza um movimento canguilhemiano em relação à historiografia das ciências.

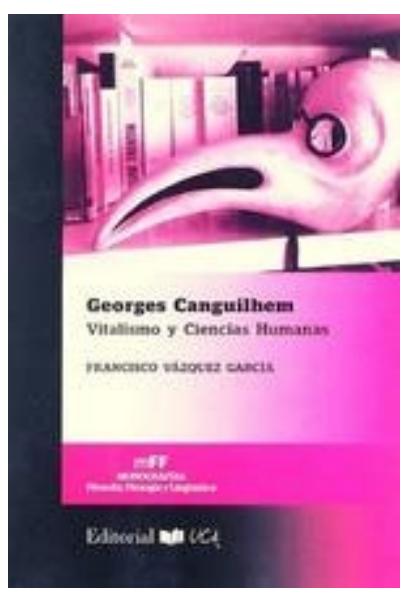

Canguilhem não costumava revisar seus trabalhos nos momentos de reedição, mas esforçava-se para preservar o que neles havia de atual. "Há algo melhor a fazer do que salpicar de reparos ou enriquecimentos um antigo texto. É tratar como nova a mesma questão", afirmou no prefácio à segunda edição de $O$ conhecimento da vida (1989). Em 1966, Canguilhem lançou o livro $O$ normal e o patológico, a reunião de dois textos: o Ensaio sobre alguns problemas relativos ao normal e ao patológico, tese de doutorado em Medicina defendida em 1943, e um texto inédito, intitulado Novas reflexões relativas ao normal e o patológico, escrito entre 1963 e 1966, quando já ocupava a presidência do Institut d'Histoire et Philosophie des Sciences et des Techniques. Dois textos, escritos num intervalo de cerca de vinte anos, abordando o mesmo problema. "Ao acrescentar algumas considerações inéditas ao meu primeiro Ensaio", escreveu Canguilhem na primeira edição do novo livro, "busco apenas fornecer um testemunho dos meus esforços, se não do meu sucesso, para conservar um problema, que eu considero fundamental, no mesmo estado de frescor que seus dados de fato, sempre em transformação" (Canguilhem, 2006, p.x).

Desde que Francisco defendeu sua monografia de licenciatura em 1984, o "estado de frescor dos dados de fato" sobre aquela teoria da história das ciências foi renovado pela abertura aos pesquisadores dos arquivos pessoal e de trabalho de Canguilhem, depositados no CAPHÉS - Centre d'Archives en Philosophie, Histoire et Éditions des Sciences, em Paris. Do ponto de vista historiográfico mais imediato, a partir de anotações de cursos, documentos inéditos e outros textos até então considerados perdidos, Francisco foi responsável por trazer à luz o diálogo entre Canguilhem e autores como Vidal de la Blache, Lucien Febvre, Marc Bloch, Georges Friedmann e Maurice Halbwachs. Dessa maneira, apresentou uma leitura renovada da obra publicada e aproximou as preocupações de Canguilhem da história social, fazendo-nos ver um "modo de escrever a história das ciências distante do internalismo de Bachelard e Koyré", como diz em sua Introdução. É preciso prestar atenção à especificidade do sentido desse distanciamento, dada por uma interpretação particular do autor sobre o significado de "internalismo", uma acusação que, em seu sentido mais rígido, não consideramos ser aplicável nem a Bachelard, nem a Koyré.

Em Georges Canguilhem. Vitalismo y Ciencias Humanas, ao longo de sete capítulos divididos em três partes, Francisco vai nos mostrando esse novo modo de escrever a história das ciências, esclarecendo suas bases filosóficas, suas circunstâncias historiográficas e seu potencial heurístico (para um "Canguilhem do século XXI", como diz). A primeira parte, com os capítulos "Filosofía y Vitalismo en Canguilhem y Ortega y Gasset" e "Vitalismo y Ontología en Canguilhem y Foucault", trata do "problema ontológico do vitalismo", cotejando a obra de Canguilhem com a dos dois filósofos. $\mathrm{Na}$ segunda parte, Francisco se dedica a explorar "o diálogo de Canguilhem com as ciências humanas", para além, portanto, de certa imagem engessada do historiador das ciências e das técnicas que, a bem dizer, hoje, só persiste nos textos de vulgarização e na imaginação dos seus detratores. Além daquele texto sobre o diálogo com a geografia 
vidaliana e os Annales, essa parte traz um capítulo intitulado "Canguilhem y la Psicología" e outro sobre "Canguilhem y los Disability Studies". Esse último torna a mostrar, agora via Canguilhem, o interesse que os livros de Francisco têm, simultaneamente, para o historiador e para o sanitarista, pois foi escrito num quadro de discussões realizado por ocasião de um estágio de pesquisa do autor espanhol no já mencionado Instituto de Medicina Social da UERJ. A última parte do livro se dedica às "recepções" de Canguilhem na França e na Espanha, com os artigos "La recepción de Canguilhem en la obra de Foucault" e "La recepción de Bachelard y Canguilhem en España (1960-1980)".

O uso e a atualização das metodologias e teorias da história de Foucault e Canguilhem são, sem dúvida, as melhores homenagens que Francisco Vázquez García poderia prestar aos dois filósofos-historiadores. Os dois livros concentram os esforços empreendidos pelo autor ao longo de décadas para pôr fim ao diálogo de surdos e de fato fazerem cooperar mutuamente a epistemologia histórica e a história cultural da vida, do corpo e da sexualidade.

\section{Referências}

CANGUILHEM, Georges. La conaissance de la vie. $2^{\mathrm{a}}$ ed. rev. e aum. Paris : Librairie Philosophique J. Vrin, 1989. (Problémes et controverses).

CANGUILHEM, Georges. Le normal et le pathologique. Paris: PUF, 2006.

\section{Sumário de Cómo hacer cosas con Foucault. Instrucciones de uso}

- Introducción. ¿ Qué significa usar a Foucault?

- Análisis de problematizaciones o Historia del presente

- Análisis de los discursos o arqueologia

- Análisis de las relaciones de poder o genealogia.

- Coda final

- Referências bibliográficas

- Notas

\section{Sumário de Georges Canguilhem. Vitalismo y Ciencias Humanas}

- Nota sobre la procedencia de los textos

- Introducción - Un canguilhem del siglo XXI

- Filosofía y Vitalismo en Canguilhem y Ortega y Gasset

- Vitalismo y Ontologia en Canguilhem y Foucault

- Canguilhem y la Psicología

- Canguilhem, la Historia y la Geografía. El encuentro con la escuela de los Annales

- Canguilhem y los Disability Studies

- La recepción de Canguilhem en la obra de Foucault

- La recepción de Bachelard y Canguilhem en España (1960-1980)

- Bibliografia 


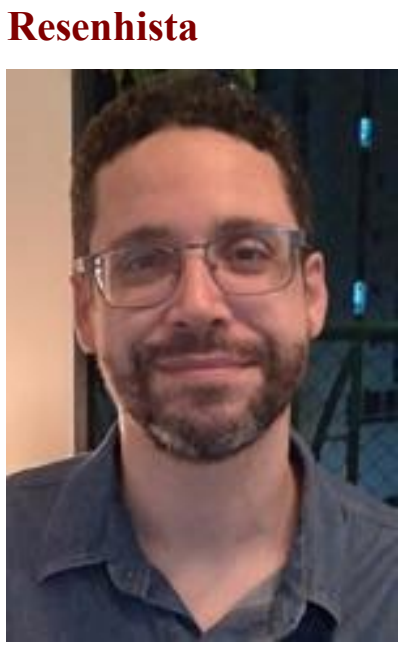

Tiago Santos Almeida - Doutor em História pela Universidade de São Paulo (USP), professor colaborador e bolsista do Programa Nacional de Pós-Doutorado (PNPD/CAPES) junto ao Programa de Pós-Graduação em História da Universidade Federal de Goiás (UFG); pesquisador visitante do Instituto de Saúde Coletiva da Universidade Federal da Bahia; coordenador do GT História da Ciência e Tecnologia da ANPUH-GO. Publicou, entre outros trabalhos, Canguilhem e a gênese do possível: estudo sobre a historicização das ciências (2018) e organizou a coletânea Historicidade e Objetividade (2017), de Lorraine Daston. Email: tsalmeida@ufg.br

\section{Para citar esta resenha}

GARCÍA, Francisco Vázquez. Cómo hacer cosas con Foucault. Instrucciones de uso. Madri: Dado Ediciones, 2021. - (Col. Filosofía y Sociedad). GARCIA, Francisco Vázquez. Georges Canguilhem. Vitalismo y Ciencias Humanas. Cádiz: Editorial UCA, 2018. Resenha de: ALMEIDA, Tiago Santos. Sobre concepções e empregos da História e da Filosofia das Ciências. Crítica Historiográfica. Natal, v.2, n.3, jan./fev. 2021. Disponíel em: https://www.criticahistoriografica.com.br/como-hacer-cosas-confoucault-instrucciones-de-uso-canguilhem-vitalismo-y-ciencias-humanas-franciscovazquez-garcia/

\section{Baixar esta resenha em PDF}

\section{Consultar outras resenhas sobre o mesmo livro}

Luis Roca Jusmet - Dorsal: Revista de Estudios Foucaultianos (2018).

Jesús González Fisac - Anales del Seminario de Historia de la Filosofía (2019).

(C) - Os autores que publicam em Crítica Historiográfica concordam com a distribuição, remixagem, adaptação e criação a partir dos seus textos, mesmo para fins comerciais, desde que lhe sejam garantidos os devidos créditos pelas criações originais. (CC BYSA) 
Pequeno no formato, grande nas potencialidades: "Hoje mando um abraço para ti, pequenina", de André Cabral

\section{Honor}

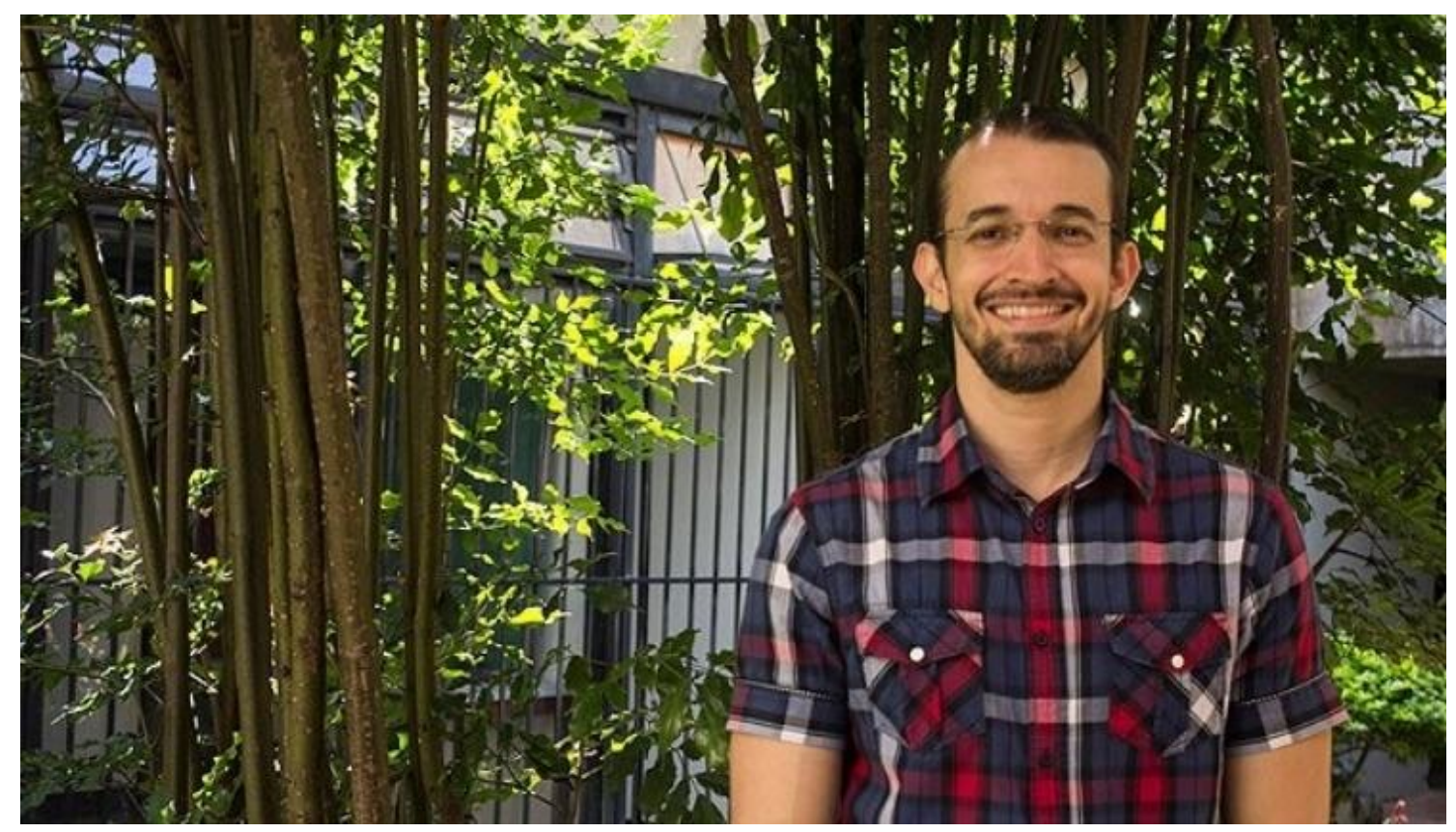

$\mathrm{UnB}$

O livro intitulado Hoje mando um abraço para ti, pequenina, de autoria de André Cabral Honor, foi publicado pela Editora Escaleras, em 2020, tem 155 páginas, possui dimensões diferenciadas dos livros físicos padrão $(12,25 \times 19 \mathrm{~cm})$ e foi impresso em papel Pólen Bold $90 \mathrm{~g} / \mathrm{m} 2$. Se incluo essas informações é para dizer que a experiência de manusear este livro é singular. Ele é inteligente e dá prazer em folhear. Ponto para a Editora Escaleras. 


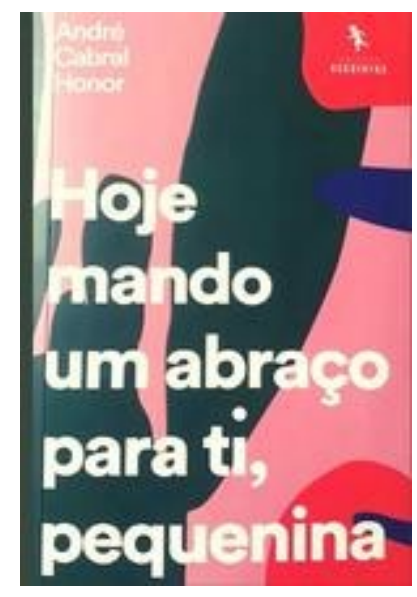

O texto foi premiado pelo Edital de fomento à literatura por meio da formação de novos autores da Fundação Biblioteca Nacional, em 2014. Aos que não conhecem ou não estão lembrados, o título remete ao refrão da música "Paraíba", de Luiz Gonzaga e Humberto Teixeira. A história narra momentos da vida do capitão-mor Jerônimo José de Melo e Castro à frente da Capitania da Paraíba. O livro é baseado em fatos históricos e, com muita licença poética, ambienta cada capítulo como pequenos filmes.

O autor é professor de História na Universidade de Brasília (UnB) e sua produção envolve a cultura Carmelita e o século XVIII, elementos presentes na narrativa do livro em questão. Apesar disso, ele não procurou facilidades para sua construção. Não há linearidade cronológica e narrador único. A cada capítulo, um contador assume a história, considerada a sua proximidade à vida do Capitão. Desvenda para o leitor aspectos da personalidade daquele que exerceu, muito provavelmente, uma das mais longevas gestões (1764 e 1797), no período colonial da América Portuguesa.

Com dados desse tipo, André Cabral Honor cria situações que incluem referências a personagens e locais da então cidade de Parahyba, atual cidade de João Pessoa, capital do estado do mesmo nome e sujeitos que representam grupos invisibilizados como escravizados e mulheres. Com frases do tipo: "Aprendera como o açúcar era branqueado com o sangue dos negros" (p.76) e "Ser mulher é estar só, Ana. Seja no claustro ou em casa" (p. 116), o autor criou um texto que nos delicia e denuncia contundentemente e, com poesia, os sofreres de tantos seres.

O que gostaria de ressaltar nessa comunicação aos possíveis leitores dessa obra são as potencialidades que nela vislumbro como leitora, profissional de História e docente, embora refletindo sempre a partir da sala de aula.

Como leitora, considero que o consumo dessa obra, por distração ou induzido por estratégias de ensino-aprendizagem, pode contribuir para a construção de leitores que saibam apreciar recursos literários e estilísticos sofisticados sem pedantismo e olhar para as coisas mundanas e sobrenaturais com graça, leveza, reconhecendo, porém, as suas complexidades. Quando articulada com a ação do qual o livro emerge - formação de escritores - o uso da obra demonstra que o acesso à cultura letrada pode fazer muito por todos. Ponto para a Fundação Biblioteca Nacional.

Como profissional de História, considero que publicações desse tipo trazem à baila as funções sociais do conhecimento histórico e as demandas por conhecimento especializado em diferentes âmbitos nos quais os profissionais de História têm que atuar. Ressalto a palavra formação para explicitar meu posicionamento de que não basta alguém se dedicar à produção de material literário ou audiovisual. Deve, também, tentar modificar os cursos de graduações e/ou especializações que induzam os formandos para diálogos com outros campos do conhecimento e espaços de atuação. Ponto para o autor que nos demonstra a dificuldade e desafios do encontro entre História e Literatura.

Como docente, seja nas graduações em História, seja na Educação Básica, considero que as potencialidades de livros como este são quase inumeráveis. Vou me restringir ao que considero mais viável: construir com ele e a partir do texto escrito situações de ensino-aprendizagem, recursos didáticos e materiais didáticos. 
O livro pode ser utilizado como recurso didático ou para produção de material didático na formação do profissional de História, por exemplo, que materialize reflexões sobre a função social de narrativas desse tipo, quando realizadas por profissionais de História, como é o seu autor. A discussão e a elaboração dos saberes necessários para a atuação dos formados em História, nessa área, ainda está por ser realizada em nossos cursos de graduação e poderiam contribuir sobremaneira para a renovação dos percursos formativos disponibilizados pelas graduações em História - licenciaturas ou Bacharelados.

Ainda pensando as potencialidades nas graduações em História, ressalto a viabilidade de exercitar a produção de material didático para a Educação Básica, sobretudo, se for efetivado o diálogo entre o expert em América Portuguesa Colonial ou temas correlatos e um profissional pesquisador da área do ensino de História. Esse trabalho conjunto converge para confecção de materiais demonstrativos, em que as estratégias de ensinoaprendizagem, muito mais que simplificações do conhecimento histórico acadêmico, se estruturem a partir das apropriações e das elaborações próprias aos objetivos e ao público do nível de ensino correspondente.

$\mathrm{Na}$ formação do cidadão, pode se aprender sobre a diversidade de formas de experiências com o tempo e as operações que os seres humanos inventam para o narrar, como a cronologia, diacronia e sincronia. Portanto, na Educação Básica, quando são tão difíceis as condições para trabalhos interdisciplinares, essa é uma das possibilidades que a publicação proporciona.

Mantendo-me nesse diapasão do diálogo entre disciplinas, o livro possibilita o trabalho sobre personagens e suas vinculações a tempos e espaços e suas formas de se identificar e se apresentar. Espaços que podem ser fictícios e imaginados, mas também que possam ser reais e palpáveis, que possamos visitar, localizar em mapas, cartografar e, até mesmo, relacioná-los às nossas memórias afetivas.

Pode se passear na cidade da Parahyba do século XVIII ou em qualquer cidade colonial em que grupos sociais dominam, resistem e (re)inventam a difícil arte de viver. Hoje mando um abraço para ti, pequenina é um livro repleto de personagens que devem ser facilmente transpostos para a experiência de outras cidades uma vez que representam grupos invisibilizados que clamam por serem ouvidos e reconhecidos nas suas diversas formas de viver. Por isso, um docente com tempo para ler, refletir, planejar-dependendo do público e do objetivo - terá condições de criar inovadores recursos. Ponto para as discussões pautadas nas Licenciaturas.

Mas, é muito importante dizer que, antes de qualquer coisa, é um livro de literatura. Boa literatura, classificável como romance histórico, produzido para encantar leitores e deixar fluir a imaginação. As indicações que faço de pautas potentes são pelo vício do olhar de quem lida com a formação de profissionais de História. As referências do autor e o contexto da origem da publicação não são amarras para o uso da narrativa inscrita em Hoje mando um abraço para ti, pequenina. Assim, convido o leitor para apreciar o Sumário transcrito abaixo. Espero que se sinta incomodado pela curiosidade dos números, das datas, tão bem definidas pelo genial Alfredo Bosi.[1]

\section{Nota}

[1] Datas. Mas o que são datas?

Datas são pontas de icebergs. 
O navegador que singra a imensidão do mar bendiz a presença dessas pontas emersas, sólidos geométricos, cubos e cilindros de gelo visíveis a olho nu e a grandes distâncias. Sem essas balizas naturais que cintilam até sob a luz noturna das estrelas, como evitar que a nau se espedace de encontro às massas submersas que não se vêem?

Datas são pontas de icebergs.

A memória das sociedades, que a velha e hoje moça história das mentalidades reconquista com zelo e paixão; a memória das sociedades, que deve ter no historiador o seu ouvinte mais atento; a memória das sociedades precisa repousar em sinais inequívocos, sempre iguais a si mesmos; e o que há de mais inequívoco e sempre igual a si mesmo do que o número? Datas são números.

Datas são pontos de luz sem os quais a densidade acumulada dos eventos pelos séculos causaria um tal negrume que seria impossível sequer vislumbrar no opaco dos tempos os vultos das personagens e as órbitas desenhadas pelas suas ações. A memória carece de nomes e de números. A memória carece de numes.

Mas de onde vem a força e a resistência dessas combinações de algarismos? 1492, 1792, $1822,1922 \ldots$ Vêm daquelas massas ocultas de que as datas são índices. Vêm da relação inextricável entre o acontecimento, que elas fixam com a sua simplicidade aritmética, e a polifonia do tempo social, do tempo cultural, do tempo corporal, que pulsa sob a linha de superfície dos eventos. BOSI, Alfredo. O tempo e os tempos. (Bosi, 1992, p.?)

\section{Referências}

NOVAES, Adauto. Tempo e história. São Paulo: Companhia das Letras: Secretaria Municipal de Cultura, 1992.

\section{Sumário de Hoje mando um abraço para ti, pequenina}

- $\quad$ Prólogo à guisa de Epílogo

- $\quad 1780$

- $\quad 1767$

- $\quad 1784$

- $\quad 1770$

- $\quad 1772$

- $\quad 1777$

- $\quad 1786$

- 1793

- $\quad$ Epílogo à guisa de Prólogo 


\section{Resenhista}

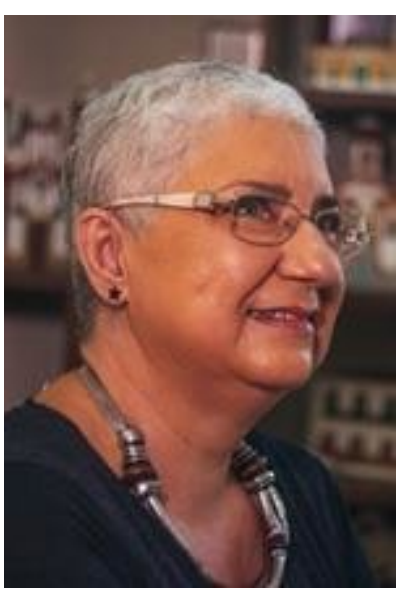

Margarida Maria Dias de Oliveira - Doutora em História pela Universidade Federal de Pernambuco (UFPE), Professora do Departamento e do Programa de Pós-Graduação em História da UFRN. Publicou, entre outros trabalhos, "Um museu de grandes novidades: em defesa de novos estudos sobre o Instituto Histórico e Geográfico Paraibano", em Estilhaços da Memória: O Nordeste e a reescrita das práticas museais no Brasil, organizado por Clovis Carvalho Britto, Marcelo Nascimento Bernardo da Cunha, Suely Moraes Cerávolo (Espaço Acadêmico, 2020) e, em co-autoria com W. O. Souza, "O curso de História da UFRN (1956-2016): alguns vestígios de memórias e pautas para a escrita de histórias", em Universidade e Ensino de História, organizado por Marieta de Moraes Ferreira (FGV, 2020). E-mail: margaridahistoria@yahoo.com.br.

\section{Para citar esta resenha}

HONOR, André Cabral. Hoje mando um abraço para ti, pequenina. JoãoPessoa/Salvador: Editora Escaleras, 2020, 155p. Resenha de: OLIVEIRA, Maria Margarida Dias de. Pequeno no formato, grande nas potencialidades: Hoje mando um abraço para ti, pequenina, de André Cabral Honor. Crítica Historiográfica. Natal, v.2, n.3, jan./fev. 2022. Disponível em: https://www.criticahistoriografica.com.br/1849/

\section{Baixar esta resenha em PDF}

(C) - Os autores que publicam em Crítica Historiográfica concordam com a distribuição, remixagem, adaptação e criação a partir dos seus textos, mesmo para fins comerciais, desde que lhe sejam garantidos os devidos créditos pelas criações originais. (CC BY$\mathrm{SA})$ 


\section{Grítica}

\section{Por uma Antropologia Histórica - resenha de "Os caminhos da pesquisa antropológica: Homenagem a Beatriz Góis Danta"s, de Eufrázia Menezes e Sílvia Góis Dantas}

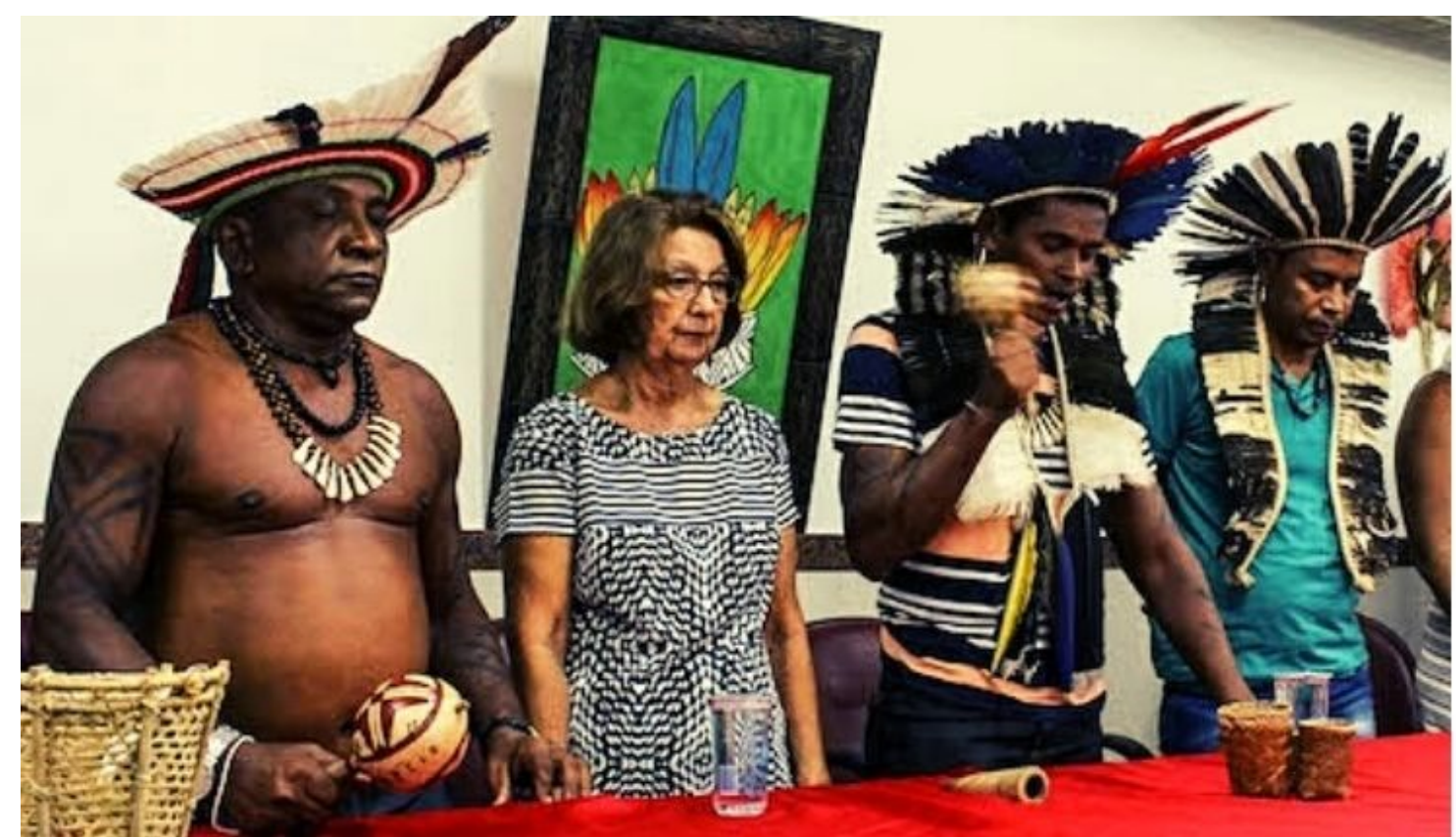

Beatriz Góis Dantas com o Cacique Lucimário Ba Xocó à sua esquerda | Foto: Carolina Timoteo/ADUFS (2019)

Os caminhos da pesquisa antropológica: homenagem a Beatriz Góis Dantas, foi lançado há dois meses, em clima fraternal, em live no Youtube (Link). Presentes ao ato, além de Beatriz Dantas, estavam as organizadoras da obra Sílvia Dantas e Eufrázia Cristina Menezes, respectivamente, filha e ex-aluna da antropóloga e historiadora Beatriz Góis Dantas. A própria homenageada, na ocasião, traçou uma "cartografia afetiva e intelectual" da inserção de vários antropólogos e historiadores em sua vida de pesquisadora, em quase seis décadas de atividades. 


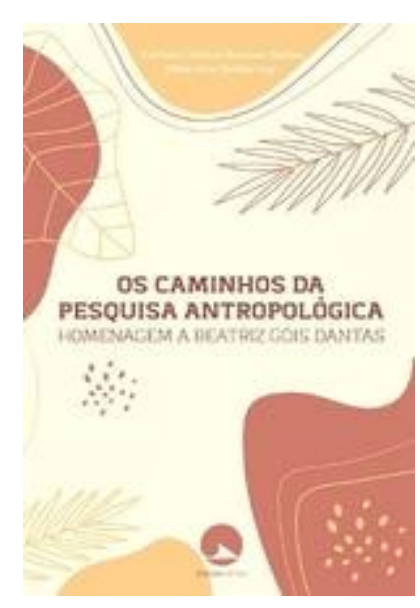

A cartografia se expressa no próprio livro que, em suas três partes (trajetória acadêmica, experiência na Antropologia e testemunhos de colegas), reúne 14 autores com atuação acadêmica local e transnacional. Há cenas familiares, relatos autobiográficos, anedóticos de trabalho, periodização clássica da carreira, reconhecimentos e agradecimentos por auxílios pessoais e até um poema de Maria Lúcia Dal Farra, dedicado à "Missionária da memória". Há descrição, crítica e reconhecimento da contribuição de Beatriz Dantas nos domínios da Arquivística, Museologia, Antropologia e (apesar do título do livro) História.

Em meio a esses estudos de diferentes áreas do conhecimento, realizados pela professora, e comentados na obra em questão, que desafiam generalistas e especialistas, gostaria de recortar o diálogo (nada consensual) entre essas duas últimas disciplinas. Se antropólogos, como F. Boas, introduziram a história em seu fazer antropológico, a escola inglesa de Radcliffe Brown e Bronislaw Malinowski adotou um modelo empiricista e a-histórico na sua escrita. No caso dos textos de Claude Lévi-Strauss, sobre História e Etnologia (1949 e 1983), identificamos certa ambiguidade, já que, no primeiro, que pode ser considerado uma introdução da Antropologia Estrutural, em sua busca de leis universais, afastava-se da história, sendo que, no último ensaio, houve certa aproximação com a história, quando afirmou que a etnologia deveria trabalhar sociedades complexas, compreendendo as rupturas históricas e as mudanças que antes pretendia ignorar (Schwarcz, 2000, p.25).

Muita tinta foi gasta nesse debate, com aproximações e afastamentos entre antropólogos e historiadores, mas, atualmente, penso haver certo consenso de que "o encontro é sempre mais rico do que o isolamento" (Agostini, 2000, p.34). Exemplar nessa direção é a contribuição do trabalho da antropóloga Beatriz Góis Dantas, tão bem sintetizada nesse livro, em homenagem aos seus oitenta anos.

Por certo, o diálogo transdisciplinar entre História e Antropologia serve de projeto intelectual para se evitar o anacronismo e o etnocentrismo, especialmente ao lidar com as culturas subalternas em suas mais variadas manifestações. Nessa interface, as pesquisas de Dantas se relacionam "aos problemas da preservação do patrimônio histórico e artístico; construção/preservação da memória de grupos e instituições sergipanas; levantamento e organização de fontes documentais" (p.92). Destacamos, nessa convergência de interesses etno-históricos, a experiência de reorganização do Arquivo Pública do Estado de Sergipe (1970) e o Levantamento de Fontes Primárias da História de Sergipe (1972), capitaneado pelo professor José Silvério Leite Fontes, do Departamento de Filosofia e História.

Parte significativas dessas temáticas é discutida pela professora Terezinha Oliva, que destaca a contribuição da homenageada na salvaguarda do patrimônio documental. Atuando no "Projeto de Reorganização do Arquivo Público Estadual de Sergipe", na década de 70 do século passado, Beatriz Dantas impulsionou a "fase heurística" da produção historiográfica sergipana, proporcionando aos estudiosos as mínimas condições para atender a pesquisa histórica. (p.155)

Essa experiência lhe deu suporte para colaborar na produção de um dossiê com documentação escrita, fundamental para a luta de reconhecimento dos Índios Xocó, no sertão do São Francisco sergipano, iniciada em 1978. Escrito com Dalmo Dallari, o livro Terra dos Índios Xocó foi publicado pela Comissão Pró-Índio de São Paulo, em 
1980, é exemplar da cuidadosa pesquisa histórica aliada à militância antropológica, no contexto da redemocratização brasileira.

Segundo Manuela Carneiro da Cunha, esse livro, publicado no calor dos acontecimentos, foi pioneiro no campo da antropologia por dar importância aos documentos históricos para a defesa dos direitos territoriais indígenas. Também foi “o germe do projeto que criou em 1985, na Universidade de São Paulo, o Núcleo de História Indígena e do Indigenismo (hoje CEestA), e seu programa de pesquisa ampla de fontes locais, apoiado pela Fapesp" (p.252). De sua participação ativa no projeto resultaram em publicações, como Repertório de documentos para a História Indígena: Arquivo Público do Estado de Sergipe (1993) e Guia Brasileiro de Fontes para a História Indígena e do Indigenismo em Arquivos Brasileiros (1980).

No mesmo diapasão, Dantas escreveu ainda um trabalho considerado clássico da antropologia brasileira, Vovô Nagô, Papai Branco: usos e abusos da África no Brasil (1988). No texto, ela revela as tentativas de legitimação e legalização do candomblé, efetuadas no Nordeste, sobretudo nas décadas de 30 e 40, com o concurso dos intelectuais que, diferentemente do que ocorreu no Sudeste em relação à umbanda, privilegiou a herança cultural africana, sobretudo a "nagô mais pura". Para ela, as categorias "puro" e "misturado" servem para classificar os terreiros de candomblé, articulando-se como esquema de forças simbólicas dos dominantes, em que se explicita de que maneira a herança cultural africana foi transformada em distintivo regional, símbolo da nação e da democracia racial e cultural brasileira. Nesse jogo de negociação, a autora sugere, por outro lado, que esta estratégia é usada também pelos terreiros para sua sobrevivência.

Como bem apontou Peter Fry, Dantas contribuiu, decisivamente, com a ideia de que "a formação do campo religioso afro-brasileiro só poderia ser entendida quando vista no contexto mais abrangente da sociedade brasileira como um todo" (p.248-249).

Essas contribuições colocam, com certeza, a professora Beatriz Góis Dantas entre as principais etno-historiadoras do Nordeste, "seja pelo volume de publicações, pela diversidade dos grupos tribais e temas pesquisados, seja ainda por sua preocupação política engajada da defesa da cidadania dos remanescentes dessa etnia", como declarou Luiz Mott (p.121).

Como recorte, esse breve texto não dá conta da intelectual multifacetada que é Beatriz Góis Dantas, pois em outras áreas, como museologia ou folclore, ela também desempenhou papel de destaque. É a própria Eufrázia Santos quem destaca: no primeiro caso, Dantas se preocupava com a educação patrimonial, e, no segundo, com "o caráter dinâmico, polifônico e relacional da cultura popular" (p.91).

Beatriz Dantas formou gerações de professores e pesquisadores, bem como gestores e técnicos da área cultural. Esse livro é justa homenagem à brilhante carreira de uma profissional dedicada a pesquisa e à docência, exercidas ao longo de décadas nas instituições educacionais e culturais em Sergipe. Nele encontramos aspectos da aventura do trabalho de antropólogo, do diálogo com outras ciências humanas, dos dilemas políticos e, principalmente, da responsabilidade social demonstrada pela pesquisadora com a experiência da cultura e a educação científica dos universitários.

\section{Referências}

AGOSTINI, Ailton José. Jacques Le Goff: por uma nova fronteira entre Antropologia e História. In: SCHWARCZ, Lilia e GOMES, Nilma Lino (org.). Antropologia e História: debate em região de fronteira. Belo Horizonte: Autêntica, 2000. 
SANTOS, Eufrázia Menezes e DANTAS, Sílvia Góis (org.). Os caminhos da pesquisa antropológica: Homenagem a Beatriz Góis Dantas. Aracaju: Criação, 2021.

SCHWARCZ, Lilia. História e Antropologia: embates em região de fronteira. In: SCHWARCZ, Lilia e GOMES, Nilma Lino (org.). Antropologia e História: debate em região de fronteira. Belo Horizonte: Autêntica, 2000.

\section{Sumário de Os caminhos da pesquisa antropológica: homenagem a Beatriz Góis Dantas}

- Parte I. Trajetória acadêmica e a paixão pela Antropologia

- O percurso de Beatriz - Ibarê Dantas

- A Antropologia vibrante de Beatriz Góis Dantas - Maria Laura Viveiros de Castro Cavalcanti

- Beatriz Góis Dantas e a Antropologia em Sergipe: notas preliminares

- Eufrázia Cristina Menezes Santos

- Parte II. Caminhos e desafios da pesquisa antropológica

- Beatriz Góis Dantas: pesquisadora, professora e ativista cultural - Luiz Mott

- Beatriz Góis Dantas: mulher perguntadeira - Osvaldo Meira Trigueiro

- Beatriz Góis Dantas e o patrimônio cultural - Terezinha Alves de Oliva

- Beatriz Góis Dantas, museologia e museu na Universidade Federal de Sergipe - Verônica Maria Menezes Nunes

- Memórias das experiências com os estudos sobre os Povos Indígenas da professora Beatriz Góis Dantas e apontamentos acerca do seu legado para a juventude pesquisadora - Diogo Francisco Cruz Monteiro e Kleber Rodrigues

- A arquitetura viva do mundo: o terreiro como epicentro - Vagner Gonçalves da Silva

- Festa, religião e cidade: experiência e expertise, em homenagem, e com imensa gratidão, à dona Beatriz -Léa Freitas Perez

- $\quad$ Parte III. Depoimentos

- Desvendando Áfricas - Peter Fry

- Para Beatriz - Manuela Carneiro da Cunha

- Carta à amiga Beatriz - Maria Thereza Lemos de Arruda Camargo

- Sobre os autores

- Beatriz Góis Dantas 


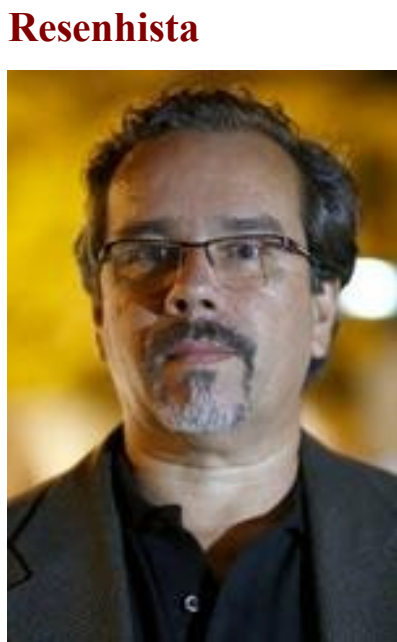

Antônio Fernando de Araújo Sá- Doutor em História pela Universidade de Brasília (UnB), professor do Departamento de História e do Mestrado em História da Universidade Federal de Sergipe e editor da Ponta de Lança - Revista Eletrônica de História, Memória \& Cultura. Publicou, entre outros títulos, Rio Sem História? Leituras sobre o Rio São Francisco (2018) e Entre sertões e representações: ensaios e estudos (2021). E-mail: fernandosa1965@gmail.com.

\section{Para citar esta resenha}

SANTOS, Eufrázia Menezes e DANTAS, Sílvia Góis (org.). Os caminhos da pesquisa antropológica: Homenagem a Beatriz Góis Dantas. Aracaju: Criação, 2021. Resenha de: SÁ, Antônio Fernando de Araújo. Por uma Antropologia Histórica. Crítica Historiográfica. Natal, v.2, n.1, jan./fev. 2022. Disponível em: https://www.criticahistoriografica.com.br/os-caminhos-da-pesquisa-antropologicahomenagem-a-beatriz-gois-dantas-eufrazia-menezes-e-silvia-gois-dantas/

\section{Baixar esta resenha em PDF}

Outras resenhas sobre Os caminhos da pesquisa antropológica: homenagem a Beatriz Góis Dantas

Claudefranklin Monteiro Santos - AJN (2021)

(C) - Os autores que publicam em Crítica Historiográfica concordam com a distribuição, remixagem, adaptação e criação a partir dos seus textos, mesmo para fins comerciais, desde que lhe sejam garantidos os devidos créditos pelas criações originais. (CC BY$\mathrm{SA})$ 


\section{Alfabetização histórica - resenha de "Letramento histórico- digital: Ensino de História e Tecnologias Digitais", de Danilo Alves da Silva}

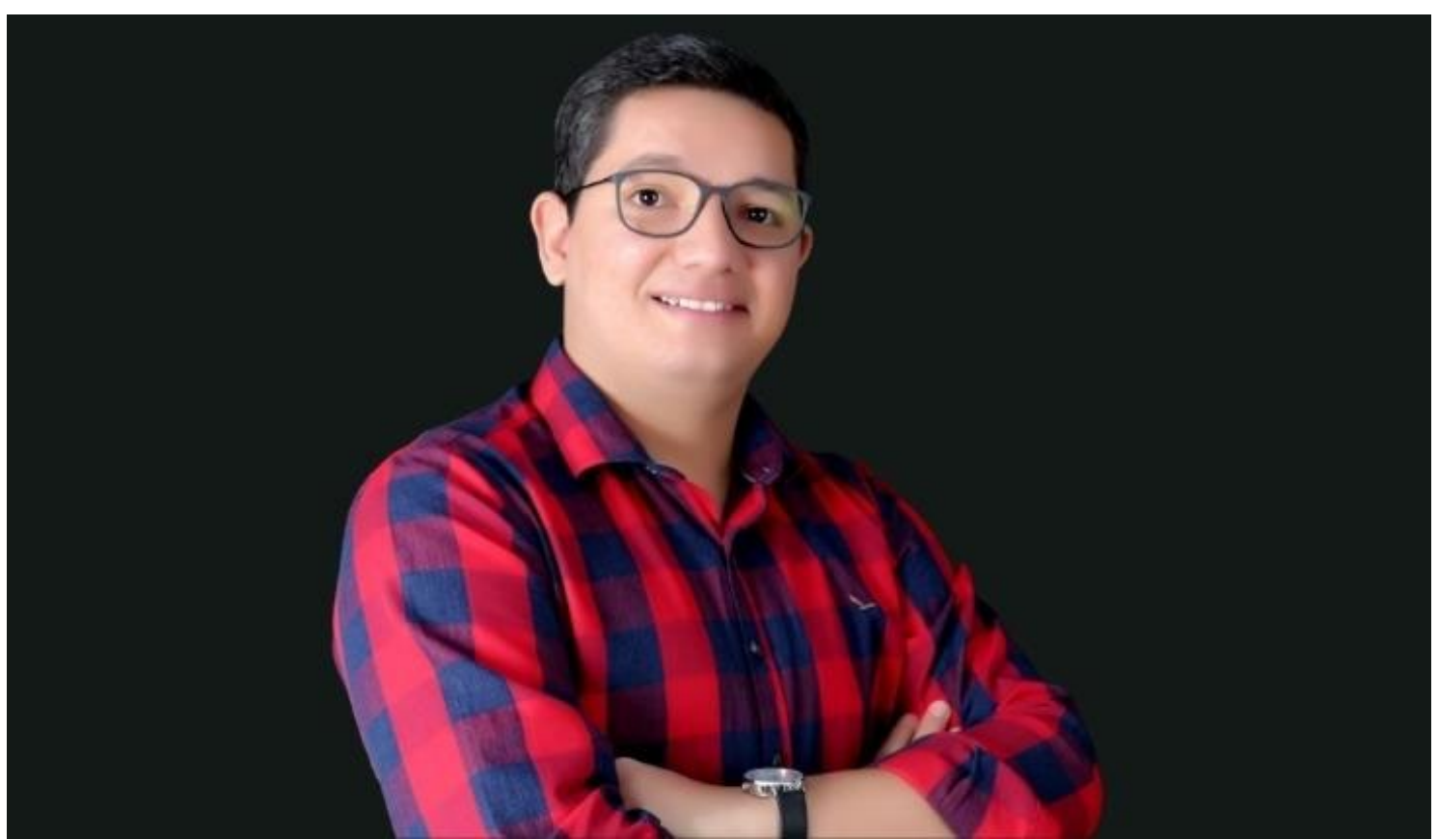

A obra Letramento Histórico-digital: ensino de História e tecnologias digitais, é fruto da dissertação de mestrado de Danilo Alves da Silva, a partir das reflexões junto ao Programa de Pós-Graduação do Mestrado Profissional em Ensino de História, da Universidade Federal do Rio Grande do Norte. A publicação pretende conceituar o letramento histórico-digital, no intuito de sistematizar uma coligação entre o Ensino de História e a cultura digital. 


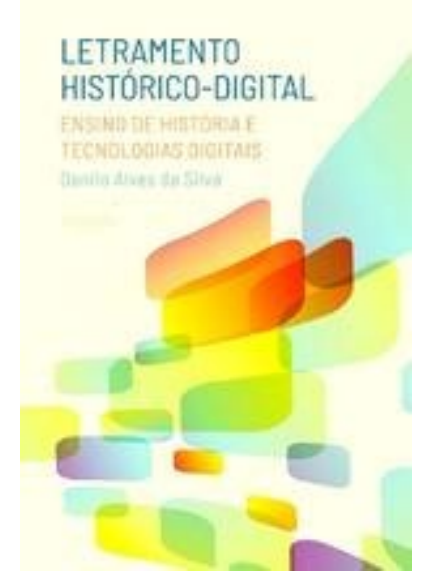

O livro está organizado em três capítulos, o que não difere da forma estrutural da própria dissertação do autor. A partir de sua prática docente em uma escola privada, na cidade de João Pessoa, Paraíba, o autor investe em uma proposição para o campo do Ensino de História. Por que não juntar a demanda por entender sobre a cultura digital nos meandros do conhecimento histórico, já com uma proposta para a sala de aula? E será essa jornada que a pessoa leitora poderá encontrar. Ele mostra como é importante que profissionais de História estejam sensíveis às demandas do século XXI, e que se apropriem do conhecimento histórico no intuito de propor interações em plataformas digitais, usando aplicativos e várias

ferramentas disponíveis para o ensino de História. Porém, ele não faz um caminho de escrita focando unicamente em justificar o seu artefato didático cultural, como a maioria das produções docentes da pós-graduação do Programa o fazem. Ele pretende conceituar um método - o letramento histórico-digital - para, então, após uma esquematização de suas discussões e leituras, passar para uma mostra dessa definição ou sistematização, que leva o nome do livro.

O capítulo primeiro, "O espaço, o tempo e o caminho da pesquisa", se propõe a trazer de forma bastante ampla a relação do autor com o espaço escolar escolhido bem como a turma com a qual decidiu trabalhar sua produção, denominada: letramento históricodigital. No geral, essa parte do capítulo ficou bastante resumida. O autor se mostrou muito efetivo em mostrar os valores morais, sociais e pedagógicos do colégio confessional em que aplicou o seu estudo e prática docente. Os apontamentos do caminho da pesquisa, conforme o título enuncia, não ganharam tantos holofotes.

Há demorada análise em todo o aporte curricular e nos documentos que emulam os princípios educacionais da escola. Talvez fosse necessária uma correlação mais efetiva entre os Parâmetros Curriculares ou a Base Nacional ou mesmo as legislações estaduais de educação para o ensino fundamental, anos finais. Nesse sentido, fazemos uma leitura menos estimulada, pois buscamos chegar no pertinente tema proposto nessa parte da obra, qual seja, mostrar sua jornada profissional e reflexão enquanto pesquisador e docente em busca de transformação no chão da escola.

Mesmo quando se percebe o esforço do autor, no sentido de se posicionar de uma maneira crítica aos princípios e parâmetros do colégio onde atua, nota-se a dificuldade, sempre vindo após alguma sinalização negativa, um contraponto elogioso. Ainda que afirme no capítulo que não tinha a intenção de historicizar sobre o colégio onde atuou para a pesquisa, ele, no mínimo, historiou de forma destacada sobre a instituição.

Por outro lado, os tópicos primeiro e último deste capítulo trazem uma boa noção do percurso e das experimentações/observações que o professor-pesquisador estava realizando em sala de aula, o que gerará a justificativa de sua trajetória reflexiva no livro. Nessa parte, ele sinaliza uma definição do letramento histórico-digital: uma metodologia, em primeiro lugar. No mesmo lugar do pódio (baseado na investigação própria da área), ele coloca o letramento histórico para que, em segundo plano, apareça o letramento digital, sempre associado à História e suas formas de pesquisa e de narrativa. Portanto, para o autor, é primordial que haja, por parte de seus alunos e alunas, prioritariamente, a orientação sobre como se faz pesquisa (ou como se pesquisa 
na ciência histórica). Posteriormente, haveria uma coligação entre esses saberes com as TDICs, gerando possibilidades de narrativas no ciberespaço.

Caso a pessoa leitora siga essa lógica (priorizando o letramento histórico), encontrará diversas leituras, amparadas pelo campo do Ensino de História, que confirmam tal assertiva. Ela será, aliás, a base da obra de Silva. A reflexão que se faz, nesse ponto, é sobre esse movimento secundarizado em que o letramento digital aparece nessa primeira sistematização anunciada pelo autor. O letramento digital é tão elementar quanto qualquer outro processo de conhecimento e aprendizagem. Portanto, aqui deixamos a reflexão que os escritos do autor nos proporcionaram: não seria necessário que o indivíduo trouxesse ou adquirisse uma alfabetização sobre as TDICs para que, assim, pudesse concomitantemente experimentar o conhecimento histórico-digital?

Ademais, cabe ressaltar que a importância do letramento digital, em diversos níveis, é algo vital para entender o que é educação no século XXI. A falta de habilidade em lidar com novos aplicativos, com as possibilidades que os softwares oferecem, a movimentação dos algoritmos em busca do consumidor cidadão, a moeda virtual bitcoin, enfim, um novo universo, literalmente, se abre para todos nós. É preciso que a sociedade da informação, como denominou Castells (2013), entenda minimamente essa dinâmica. Uma alfabetização digital é, sim, necessária para que outros letramentos ocorram, e os letramentos, digital e histórico podem e devem ocorrer juntos nesse processo, sem hierarquização.

Faz-se aqui uma pequena ressalva quanto o seguinte trecho: "[...] na esteira disso [da importância de que discentes produzam e tenham narrativas históricas], utilizar as tecnologias digitais talvez seja uma alternativa para aproximar os estudantes de um conhecimento que para eles tem se tornado cansativo e chato" (p. 61). Ele parece reforçar a questão da centralidade do histórico ao invés da paridade com o digital, nos letramentos, chegando a correr o risco de a tecnologia ser significada como um entretenimento para a sala de aula. A grande inquietação e reflexão é: se usamos lápis, quadro branco, massa de modelar, recortes de revistas e podemos desenvolver o letramento histórico, em que medida um letramento histórico-digital seria distinto, lançando mão das TDICs, do letramento apenas histórico? O que o tipifica?

No capítulo seguinte, Cultura Digital e o Ensino de História, o autor traz uma compreensão mais clara, logo no início do capítulo, sobre a necessidade de letramento digital dentro dessa nova cultura de acesso mais amplo ao ciberespaço. Ele admite que é vital o uso crítico das tecnologias digitais, porém, aliando ao conhecimento histórico. A ideia é conectar a ciência histórica na escola como uma prática essencial para desenvolver essa criticidade no uso dos ambientes digitais.

O argumento principal é que haja, por parte do ensino escolar de História, "[...] uma formação de sujeitos que aprendam a pensar historicamente, apropriando-se das tecnologias digitais de modo simultâneo" (p.69). Esse fim deveria ser sempre nosso foco quando utilizamos as TDICs no espaço escolar, do ensino básico à universidade. É fundamental entendermos que não há apenas as fontes digitalizadas dos grandes arquivos disponibilizados para o público, no ciberespaço. Há fontes que nasceram no digital e só são explicadas e entendidas se respeitado o território que justifica sua existência.

Além disso, há algo fundamental a ser refutado. O autor afirma que "a transição de uma cultura analógica para uma cultura digital é um movimento dinâmico e complexo [...]" (p.69-70). É importante ressaltar que o analógico não está sendo sobrepassado por outro movimento cultural. Talvez, nunca o será. As culturas estão coexistindo e se 
relacionando em um ritmo que inclusive desafia as próprias noções temporais que a humanidade usa para se organizar, como dias, meses, horas, etc. Mas, não estamos rumo à extinção do analógico. O movimento de digitalização, como mais uma possibilidade de acesso e divulgação de documentos oficiais ou acervos de memória, pode provar que precisamos e vivemos do analógico, no qual se afirma a cultura digital.

O que seria uma rede social ou um e-mail ou direct se não fosse a coexistência de grupos de amigos presenciais, das cartas e bilhetes, dos anúncios em jornais impressos ou na rádio? No espaço escolar experimentamos situação idêntica, dado que ali temos a nossa cultura replicada de muitas formas. Então, não sóé importante não ignorar o digital e a sua produção para a História e para o ensino, como também é vital que não pensemos que é um momento de transição para outra cultura como se houvesse uma obsolescência programada para o analógico.

Feita essa ressalva, o capítulo traz, em seu primeiro apartado, uma boa síntese que aproximará a pessoa leitora de como a computação e a informática foram sendo parceiras dos profissionais da História, ampliando discussões, pensando em formas de otimizar o trabalho de pesquisa, sobretudo, com poucos debates e, ainda, relacionando TDICs ao ensino em nosso campo. O autor se ampara bastante em três historiadores, entre os quais Anita Lucchesi é a mais referenciada. Nesse sentido, pode-se perceber que a argumentação dele sobre a ideia transicional de uma linguagem para outra, ou seja, do analógico para o digital, tem como mote o que a historiadora sustenta em sua dissertação de mestrado, de 2014. Nesse sentido, é preciso reiterar que, além de uma transição, temos uma inclusão de novas linguagens, mediadas por novas tecnologias. Não perdemos a oralidade, nem ganhamos a linguagem audiovisual, por exemplo, porque temos a internet. Ao revés, são estas formas de comunicar que dão bastante sentido para a atuação no ciberespaço. Ademais, isso que estamos a experimentar, desde os anos 2000, mais ou menos, é em parte novidade e, em parte, a relação dialética dessas linguagens já existentes com o que temos de novo, como a linguagem de programação, alfabetização digital e comunicação nos ambientes virtuais.

Essa seção da obra foi sucinta, se comparada ao tópico seguinte, em que o autor busca mostrar a importância da didática da História para o ensino. Nesse viés, talvez, o título do capítulo, que indica a cultura digital em primeiro plano, pudesse dar lugar ao Ensino de História, dado que é o argumento mais justificado no capítulo, tendo a cultura digital ou a relação com as TDICs ficado em um plano complementar. A discussão sobre o tema do capítulo dois está bem consubstanciada, sobretudo o tópico segundo, dando bastante dinamicidade ao texto e construindo uma linha argumentativa com relevante bibliografia e sustentando seu ponto de vista. Fica evidente que o autor está decidido a incorporar a sua experiência com as tecnologias em sala, como algo que se oponha ao campo epistemológico da Educação. Portanto, seu olhar é sobre a aprendizagem histórica dentro da Didática da História, preconizada por Rüsen (2010) e desenvolvida por Saddi (2012). Ainda que use muitas outras referências, estas são fundamentais para entender os rumos que ele dá para sua explanação sobre a importância do ensino de História e da operação historiográfica para construção de sua produção didática, que será desenvolvida no último capítulo.

Aqui, há uma nomenclatura que se faz necessário pontuar. É a expressão "nativos digitais", usualmente incorporada nos meios acadêmicos e jornalísticos. Ainda que o próprio criador do termo (Marc Prensky) tenha dado menor importância à categorização aos nascidos entre os anos 1980 e 1990, ele continua a ser trazido de forma naturalizada nos textos acadêmicos. O mais importante é que entendamos que não existe obviedade na associação do ano de nascimento das pessoas com o surgimento de uma tecnologia, 
sobretudo em um país onde as desigualdades são a regra e não a exceção. Sendo assim, é proibitivo que se catalogue as gerações dentro de uma terminologia sobre a qual, basicamente, não se tem evidência (Kennedy, et al, 2007), muito menos quando associada ao espaço escolar (Benini; Murray, 2013; Bennet et al., 2008).

Neste tópico do capítulo segundo, vale ressaltar que o autor retoma o seu letramento histórico-digital. Para ele, desenvolvendo este método, espera-se que o alunado consiga usar o espaço digital de forma hábil, para alcançar noções temporais, consciência histórica e que veja significado do saber histórico para suas vidas.

No último tópico, o mais focado na questão do letramento histórico-digital, aparecem, várias vezes, definições que demonstram com clareza a posição do autor em relação a uma experiência em sala de aula que valorize a didática própria da História e, ao mesmo tempo, se utilize do digital para capacitar, dentro do conhecimento da área, sobre o seu uso e ocupação do ciberespaço. Nesse sentido, a questão do digital está em plano secundário, inclusive na pouco expressiva bibliografia sobre o tema, sendo um aspecto extra de interação e consonância com as demandas que ele percebe em sala e no perfil discente de seu espaço escolar. Importante é frisar, também, que não há uma discussão com autorias que já trouxeram o termo letramento histórico-digital e/ou aproximações em seus trabalhos científicos, como os S. Livingstone (2011), M. Soares (2012) e M. Costa (2015) e isso representa uma fragilidade que poderia ser sanada em uma provável segunda edição.

O autor avalia que o letramento histórico-digital ajuda os discentes a pensar historicamente e estimula "habilidades digitais ligadas à investigação histórica, capacitando os sujeitos a se orientarem e darem sentido ao tempo" (p.125-26). O capítulo tem a explanação do passo a passo do planejamento e execução da atividade proposta pelo docente. É um aprendizado para todas(os) que o lerem. Trata-se de uma execução muito boa com as avaliações das suas percepções, logo após cada passo de sua experiência. Há boa interlocução entre o que ele propôs e defendeu como prática docente durante os dois capítulos anteriores. O autor utiliza o que a escola privada, na qual trabalha, fornece, de forma criativa e interativa, a partir das bases do conhecimento científico do campo da História. Há atividades para que as(os) discentes elaborem fora da sala, como entrevistas utilizando dispositivos eletrônicos e há planejamento síncrono, em sala de aula, para construir e orientar a turma em cada etapa de sua metodologia para o letramento histórico-digital.

Interessa notar que, durante a narrativa e análise sobre os processos do letramento, o próprio autor evidencia algo já analisado aqui. Ele percebe que nem todos os alunos estavam aptos ao uso de dispositivos móveis ou conseguiam trazer alguma expertise sobre a própria técnica no uso de aplicativos. Essa insuficiência demonstra, assim como os relatos sobre o não reconhecimento de fontes digitais ou mesmo a dificuldade de encontrar os conteúdos e fazer qualquer análise, que o letramento digital é objeto de reflexão interdisciplinar fundamental. $\mathrm{O}$ consumo de dispositivos móveis, em uma turma com condições materiais confortáveis, em comparação à maioria da população em escola pública, mesmo naturalizado por aquele nicho, não garante uma relação diferente com a de qualquer pessoa, em qualquer idade, obrigada a se adaptar e aprender sobre o mundo digital. Logo, a ideia de nativos digitais, neste capítulo, resulta em uma terminologia que não resiste, sobretudo em um país que tarda em compreender que cultura digital não é ter dispositivos e internet (quando há), mas é saber como usar e se posicionar no ciberespaço. 
Vale salientar, por fim, que a obra cumpre os objetivos primeiros, ou seja, conceituar o letramento histórico-digital e correlacionar Ensino de História e cultura digital. O autor é coerente em sua iniciativa, especialmente, porque apresenta uma base esquemática clara sobre o método e ensaia a sua aplicação, apontando dificuldades e experimentos no campo do Ensino de História, a partir do ambiente escolar. É um trabalho que suscita muitas reflexões e estimula nossa criticidade.

\section{Referências}

BENINI, Silvia; MURRAY, Liam. Critically Evaluating Prensky in a Language Learning Context: The "Digital Natives/Immigrants Debate" and its Implications for CALL. Eurocall 2013. Évora, Portugal, p. 25-30, 2013. [Link]. Acesso em 25 jun. 2021.

CASTELLS, Manuel. A sociedade em rede. Rio de janeiro: Paz e Terra, 2013.

COSTA, Marcella. Currículo, História e Tecnologia: que articulação na formação inicial de professores? (Mestrado em Educação).Universidade do Rio de Janeiro, Rio de Janeiro, 2015. Acesso em 25 jun. 2021.

LIVINGSTONE, Sonia. Internet literacy: a negociação dos jovens com as novas oportunidades on-line. Matrizes, São Paulo, ano 4, n. 2, jan./jun. 2011, p. 11-42. [Link] Acesso em 27 jun. 2021

PRENSKY, Marc. (2009). H. sapiens digital: From digital immigrants and digital natives to digital wisdom. Journal of Online Education, v. 5, n. 3, p. 1-9, 2009. [Link] Acesso em 25 jun. 2021.

PRENSKY, Marc. Digital natives, digital immigrants, part 1. On the Horizon, v. 9, n. 5, p. 1-6, 2001a. [Link]. Acesso em 25 jun. 2021.

PRENSKY, Marc. Digital natives, digital immigrants, part 2: Do they really think differently? On the Horizon, v. 9, n. 6, p. 1-6, 2001b. [Link] Acesso em 25 jun. 2021.

SOARES, Magda. Novas práticas de leitura e escrita: letramento na cibercultura. Educação e Sociedade, Campinas, v. 23, n. 81, p. 143-160, 2002. [Link] Acesso em 27 jun. 2021

\section{Sumário de Letramento histórico-digital: Ensino de História e Tecnologias Digitais}

- Apresentação

- Agradecimentos

- Lista de siglas e abreviações

- Introdução

- 1. O espaço, o tempo e o caminho da pesquisa

- Nas dobras do caminho: dos porquês às motivações

- Nas dobras do espaço: tensões e possibilidades

- Nas dobras do tempo: o ensino de História no Colégio Pio X

- Nas dobras do saber: caracterizando a investigação

- 2. Cultura digital e o Ensino de História

- Uma discussão historiográfica sobre História Digital e sua relação com o ensino de História

- A operação historiográfica e o ensino de História

- Letramento histórico-digital: a construção de habilidades digitais e da competência narrativa no ensino de História 
- 3. O caminho investigativo na plataforma digital Moodle

- O primeiro passo do letramento histórico-digital: investigação histórica

- O desenvolvimento da competência digital: procedimentos executdos pelos estudantes no Moodle

- A competência narrativa no processo de letramento histórico-digital

- Considerações finais

- Referências

\section{Live de lançamento [Link]}

\section{Resenhista}

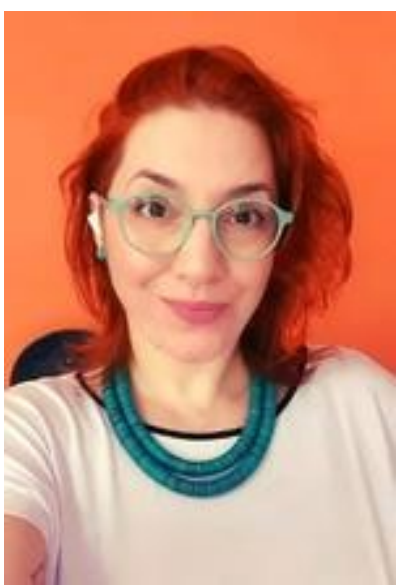

Vanessa Spinosa - Doutora em História e docente do Departamento de História da Universidade Federal do Rio Grande do Norte (Campus Caicó) e do Programa de PósGraduação Mestrado Profissional em Ensino de História, pela mesma instituição. Publicou, entre outros trabalhos, "Formação do futuro-presente: a docência em História no espectro da experiência digital no ensino remoto", em coautoria com Marcella Albaine Farias da Costa, em Formação docente e currículo: Conhecimentos, sujeitos e territórios, organizado por Carmen Teresa Gabriel e Marcus Leonardo Bomfim (Mauad X, 2021), "Ciberespaço, letramento e docência: experiência com TDICs no Ensino de História", em História em jogo: as questões do tempo presente e os desafios do ensino de história, organizado por Airan dos Santos Borges de Oliveira e Maria da Conceição da Silva Costa (Desalinho, 2020) e, em co-autoria com Danilo Nogueira de Medeiros, "Ensino de História no ensino superior: práticas educativas para a emancipação discente no ciberespaço", nos Anais do XI Encontro Nacional Perspectivas do Ensino de História (ABEH, 2021).E-mail: vanessa.spinosa@ufrn.br

\section{Referências desta resenha}

SILVA, Danilo Alves. Letramento histórico-digital: Ensino de História e Tecnologias Digitais. Rio de Janeiro: Autografia, 2020. 162p. Resenha de: SPINOSA, Vanessa. Alfabetização histórica . Crítica Historiográfica. Natal, v.2, n.3, jan./fev. 2021. Disponível em: https://www.criticahistoriografica.com.br/letramento-historico-digitalensino-de-historia-e-tecnologias-digitais-danilo-alves-da-silva/

\section{Baixar esta resenha em PDF}

(C) - Os autores que publicam em Crítica Historiográfica concordam com a distribuição, remixagem, adaptação e criação a partir dos seus textos, mesmo para fins comerciais, desde que lhe sejam garantidos os devidos créditos pelas criações originais. (CC BY$\mathrm{SA})$ 


\section{Griticariográfica}

\section{Tecnologias digitais no ensino de História - Resenha de "Museus virtuais e jogos digitais: novas linguagens para o estudo da história", de Lynn Rosalina Gama Alves, Alfredo Matta e Helyon Telles}

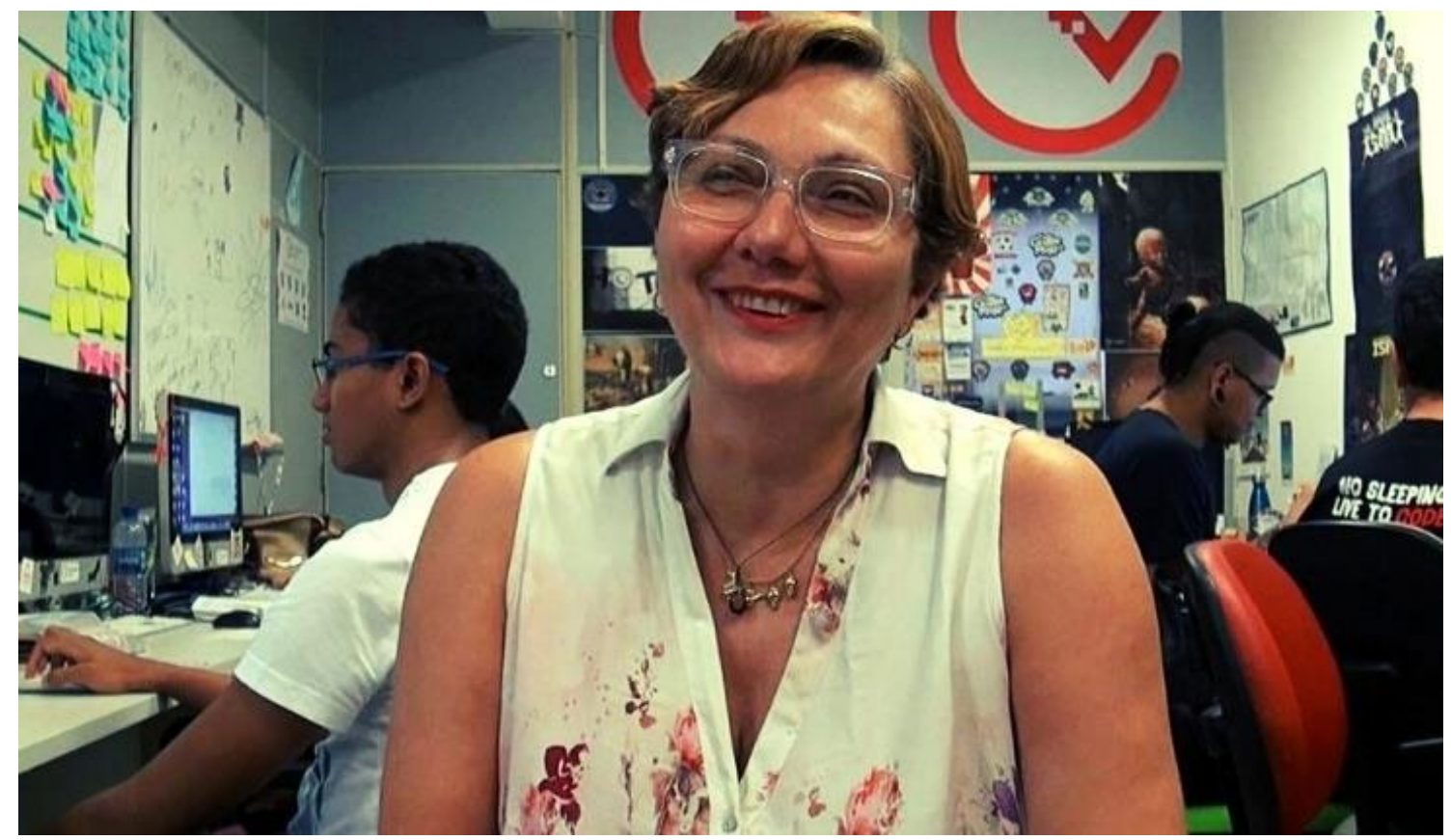

Capacitor (2018)

A obra Museus virtuais e Jogos digitais - Novas linguagens para o estudo da História, de Lynn Alves, Helyon Viana e Alfredo Matta, é um livro sobre recursos digitais para o ensino de História na educação básica com foco na temática da gamificação e dos museus virtuais. O livro é divido em duas partes. A primeira tem sete capítulos e maior incidência de tema nos games. A segunda parte possui cinco capítulos, sendo três dedicados aos museus e dois sobre os jogos de RPG (Role Playing Game). Trata-se de um compêndio destinado à divulgação dos trabalhos dos orientandos do professor Alfredo Matta que atua na área do Ensino de História desenvolvendo práticas de ensino, pesquisa e extensão para o ensino de História, na Universidade do Estado da Bahia. 


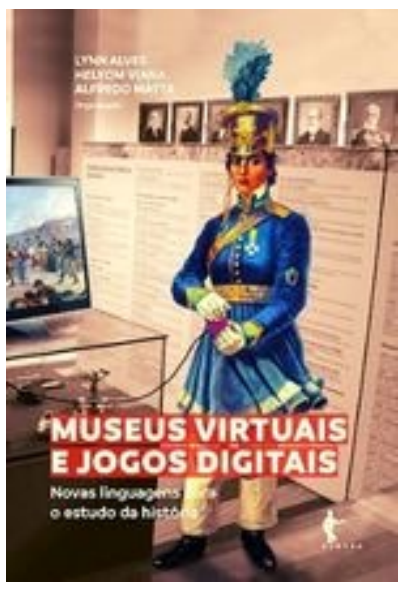

O objetivo principal do livro é incentivar a divulgação dos trabalhos dos intelectuais que pesquisam sobre a temática do ensino de História aplicado à tecnologia. Os autores declaram o desejo de transformar professores portugueses e brasileiros, efetivamente, em protagonistas, que percebam o potencial da aprendizagem história para além da simples memorização.

Os capítulos iniciais da obra apresentam artigos extensos com uma visão metodológica, experimentando procedimentos para colocar o jogador com o papel principal da história e aplicando a educação histórica dos jogos e museus virtuais. O livro é, possivelmente, destinado para professores e pesquisadores da educação básica pois, em alguns dos escritos, é possível localizar assuntos que são destaques desde o período inicial da educação até os anos finais. A obra, todavia, contribui com sugestões de pesquisas para a História e para a grande área da Educação.

Esta primeira parte da obra é um aporte bastante centrado na aprendizagem histórica do aluno, evidenciado pelos primeiros artigos que ressaltam os jogos de protagonismo em primeira pessoa, oferecendo ao jogador a sensação de vivenciar fatos como épocas históricas, monumentos antigos e cenários guerra e pós-guerra, assuntos que fazem parte de séries tanto do ensino fundamental como do ensino médio. São experiências que contribuem para o exercício das metodologias ativas no ensino de História, tirando o aluno do seu lugar passivo e agente receptor de conteúdo para auxiliar relatos da experiência virtual vivenciada, possibilitando que tanto os jogos como os museus virtuais sejam aptos a proporcionar ao aluno essa dinâmica.

O primeiro capítulo foca na experiência de protagonismo do indivíduo em contato com o recurso tecnológico do jogo. Iniciando com uma experiência detalhada sobre a série de jogos uncharted, o jogo, que usa aventura de reunir relíquias e monumentos Históricos como critério para avançar de fase, apresenta várias sugestões pedagógicas sobre como seria possível empregá-lo nas aulas de História, fato afirmado quando o autor descreve como apresentar as relíquias durante as aulas da construção de civilizações antigas.

O segundo e único capítulo desta parte que discorre sobre museus faz um relato de experiências nos museus digitais para a formação da construção social de alunos em idade escolar. O capítulo historiciza o início da formação dos museus e a mudança da sua concepção. $\mathrm{O}$ trecho apresenta alguns museus que funcionam totalmente de maneira digital e também faz a relação dos jogos digitais educativos e o seu uso no ensino.

O capítulo três é uma contribuição do colaborador Helyon Viana Telles, uma comunicação dos games educacionais e a crítica sobre trabalhos de investigação da relação História e jogos eletrônicos brasileiros, artigo focado para o campo da pesquisa. Os outros quatro falam exclusivamente da experiência game e suas contribuições ricas sobre simulações do passado para o jogador em primeira pessoa, entrelaçados pela inteligência artificial e os conhecimentos históricos disponíveis. Como afirma o autor, "as I.A contribuem assim como diz o autor para melhorar a experiência e imersão do usuário nos jogos e nas experiências museais como é o caso dos Histgames (Hist= História;Game=jogo) jogos educacionais focados na disciplina de História."

O Histgame apresentado no artigo desta primeira parte é um jogo de perguntas e respostas sendo apenas uma correta. Ao final do jogo, e com o acúmulo de respostas corretas, os jogadores são classificados por um ranking. A obra não se limita a este tipo 
de jogo. Ela traz uma lista vasta de jogos educacionais para a disciplina na qual professores de quase todas as séries do ensino básico encontrarão sugestões para inserir em suas aulas. Além de relatar o uso dos jogos, os autores correlacionam jogos e assuntos do currículo escolar. Encontramos estas sugestões tanto no corpo do artigo como logo após a conclusão em uma relação em que todos foram analisados.

No capítulo quatro, o livro apresenta uma catalogação de jogos que tem como cenário a Guerra Fria. São descritos a sua construção e o seu uso para uma explanação educacional. Há também índice de games sobre a colonização da América, com personagens na condição de navegadores e escravos, cenários ricos em detalhes da época e aventuras que colocam o jogador como personagem da História. Estes são alguns dos que aparecem neste primeiro extrato. No final de alguns capítulos, os autores se preocuparam em disponibilizar o catálogo dos jogos usados nos estudos para abordar algumas temáticas. É uma pena que nem todos os autores de capítulos procedam da mesma maneira.

Apesar dessas qualidades, uma ausência ganha destaque. No livro, não se debate sobre a aquisição dos recursos e dos meios facilitadores para aplicar tais jogos e visitas em museus para alunos do ensino público, pois são meios que demandam produtos de uso coletivo e para que estes circulem em todos os ambientes escolares é necessário o investimento governamental. Essa falta desperta uma sensação romantizada de que a aplicabilidade destes é algo pessoal de cada professor.

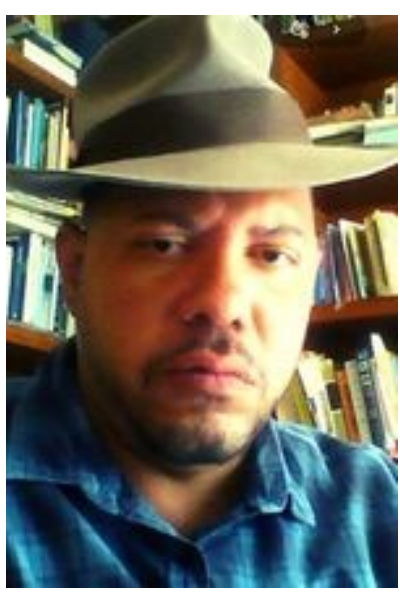

Figura 1 Helyom Telles

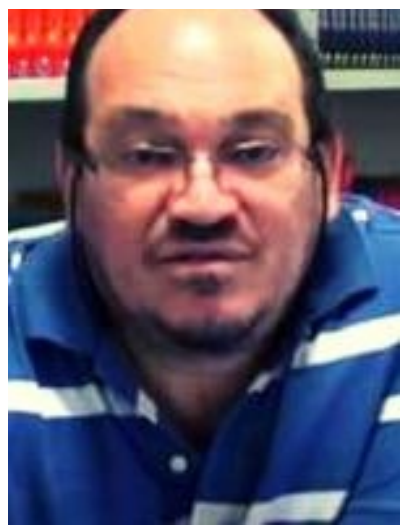

Figura 2 Alfredo Matta

A segunda parte da obra é constituída por artigos um pouco mais curtos e centrados nas teorias e conceitos, formas de usar os jogos e museus virtuais nas aulas e nas pesquisas. Há mais capítulos sobre os museus virtuais e como a experiência de uma vivência dentro desse universo museológico contribui para a construção social do indivíduo.

Para esse tema, são dedicados três dos cinco capítulos do livro. $\mathrm{O}$ primeiro artigo aborda como os museus virtuais contribuem para a aquisição das competências e conhecimentos com a apresentação do projeto UC Digital que é a experiência de espaço museológico a céu aberto com um roteiro préestabelecido de acordo com os interesses de cada turma.

O segundo capítulo possui abordagem um pouco rasa em relação aos jogos digitais e os museus digitais. É um texto que historiciza sobre o conteúdo da História como ciência e tem o objetivo de relembrar que os museus não possuem apenas a função de recurso didático. Museu é um espaço de comunicação a serviço de cultura da comunidade.

O terceiro capítulo explana sobre a temática museológica: o relato de experiência obtida pelo autor em pesquisa dentro do museu 3d do teatro São João da Bahia. Esse texto contribui para ampliar as formas de pesquisas transdisciplinares, pois o estudo foi elaborado com contribuição de diversas áreas como música e arte. O tópico é rico em contribuições para pesquisas e projetos pedagógicos escolares, uma vez que o editor deixa várias inquietações em aberto sobre a sua análise do exercício. 
O quarto capítulo da obra disserta sobre os jogos RPG (Role Playing Game) como instrumento pedagógico para o ensino de História. Este jogo é configurado por narrativas, interpretações e tomadas de decisão. Foi modelado um jogo para desenvolver o pensar Histórico sobre a abolição da escravidão com objetivo de gerar uma aprendizagem crítica e significativa para os alunos participantes. Esse trecho aponta uma crítica sobre metodologias usadas pelos professores de História e as suas aulas tradicionais e expositivas, porém, a falta de recursos e materiais digitais é uma questão de debate coletivo.

O quinto e último capítulo trata do uso dos mapas cartográficos em game para o uso do RPG Histórico. O nome do jogo aqui relatado é RPG 2 de julho, uma referência direta ao movimento de independência do Brasil na Bahia, simulando várias fases da guerra . O objetivo deste recurso é ampliar as possibilidades pedagógicas para o ensino utilizando as tecnologias digitais. É claramente mais um fomento ao uso de metodologias ativas para a História. O capítulo possui contribuição significativa e marcante, narrando, além dos usos, a importância de colocar o aluno no papel interativo do jogador adquirindo uma aprendizagem participativa.

$\mathrm{O}$ incentivo à divulgação de recursos tecnológicos para o ensino de História é ratificado do início ao fim desta obra, fazendo cumprir objetivos anunciados pelos autores. Contudo, senti falta de questionamentos sobre o acesso para estes meios de maneira inclusiva e colaborativa. Apenas um fragmento da segunda parte faz uma abordagem superficial sobre a questão, porém, aponta o docente como principal autor da falta de uso e ampliação destes meios. $\mathrm{O}$ enfrentamento dessas questões permitiria reduzir a negativa destes recursos e atividades em sala de aula. Apesar desses senões, a obra em questão deve ser lida pelos pedagogos, professores de História e Geografia e pesquisadores da grande área da Educação, Historiadores e graduandos da área de licenciaturas, dado o seu potencial para divulgar métodos digitais e tecnológicos para práticas do ensino de História na sala de aula, e o esforço e preocupação em divulgar estas pesquisas que é algo ainda em crescimento no Brasil.

\section{Sumário de Museus virtuais e jogos digitais: novas linguagens para o estudo da história}

- A História e suas interfaces - Lynn Rosalina Gama Alves e Helyom Viana Telles

○ Parte I. Museus, jogos digitais e o Ensino de História

- Games e História: monumentos digitais - Ivana Carolina Alves da Silva Souza e Lynn Rosalina Gama Alves

- Jogar e compartilhar: por uma descrição densa dos jogos eletrônicos baseados em simulações do passado - Helyon Viana Telles

- Games e Geopolítica: uma análise sobre a influência do discurso geoestratégico norte-americano em Supreme Ruler Cold War - Diogo Trindade Alves de Carvalho

- História em jogo: aspectos da colonização da América e elogio do colonizador Hezrom Vieira Costa Lima

- Inteligência artificial, jogos digirais e Ensino de História no século XXI: multiversos e transformações educacionais - Bergston Luan Santos e Ecídio Pimenta Arruda

- Os jogos digitais e o ensino de História: o caso do Histgame - Marcella Albaine Farias da Costa, Luisa da Fonseca Tavares, Diana Jane Barbosa da Silva e Rayane de Castro Guedes 
- Parte II. Museus Virtuais, RPG e o ensino de História

- Museus virtuais interativos enquanto artefactos digitais para a aquisição de competências e conhecimentos: o Projeto UC Digital - Sara Dias-Trindade, Ana Isabel Ribeiro e José Antônio Moreira

- Museu Virtual em 3D, Teatro São João da Bahia: uma abordagem socioconstrutivista Maria Antonia Lima Gomes, Alfredo Eurico Rodrigues Matta e Lucas Robato

- RPG Liberdade: instrumento pedagógico para o ensino de História - Antônio Lázaro Pereira de Souza

- Uso de mapa cartográfico em game RPG Histórico - Josenilda Mesquita, Fabricio Moreira e Alfredo Eurico Rodrigues Matta

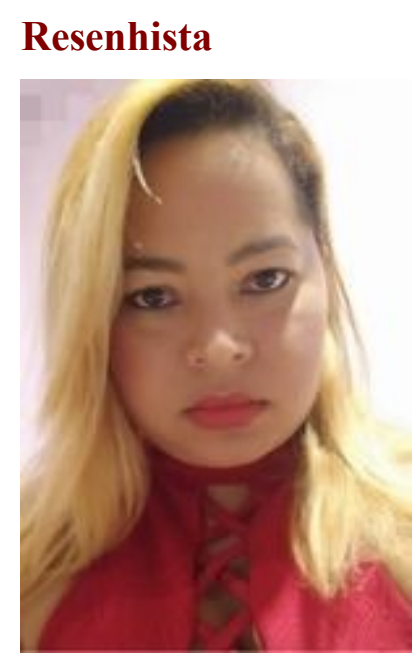

Marcia Evangelista da Silva - Mestre em Ensino de História pela Universidade Federal de Sergipe, publicou

"Alfabetização histórica e a BNCC em escolas municipais de Barra dos Coqueiros/Sergipe", "Ensino-aprendizagem de História nos Anos Iniciais do Ensino Fundamental: Estudo de caso em escolas municipais de Barra dos Coqueiros/Sergipe" e "Caminhos da aprendizagem histórica: ensino, reflexão e ação". E-mail: marciaevangelistasilv@outlook.com

\section{Referências desta resenha}

ALVES, Lynn Rosalina Gama; MATTA, Alfredo; TELLES, Helyon (Org.) Museus virtuais e jogos digitais: novas linguagens para o estudo da história. Salvador: EDUFBA, 2019. Resenha de: SANTOS, Marcia Evangelista da Silva. Tecnologias digitais no Ensino de História. Crítica Historiográfica. Natal, v.2, n.1, jan./fev. 2022. Disponível em: https://www.criticahistoriografica.com.br/1943/

\section{Baixar esta resenha em PDF}

(C) - Os autores que publicam em Crítica Historiográfica concordam com a distribuição, remixagem, adaptação e criação a partir dos seus textos, mesmo para fins comerciais, desde que lhe sejam garantidos os devidos créditos pelas criações originais. (CC BY$\mathrm{SA})$ 


\section{À margem da lei - resenha de "'Fumo de Negro': a criminalização da maconha no pós-abolição", de Luísa Saad}

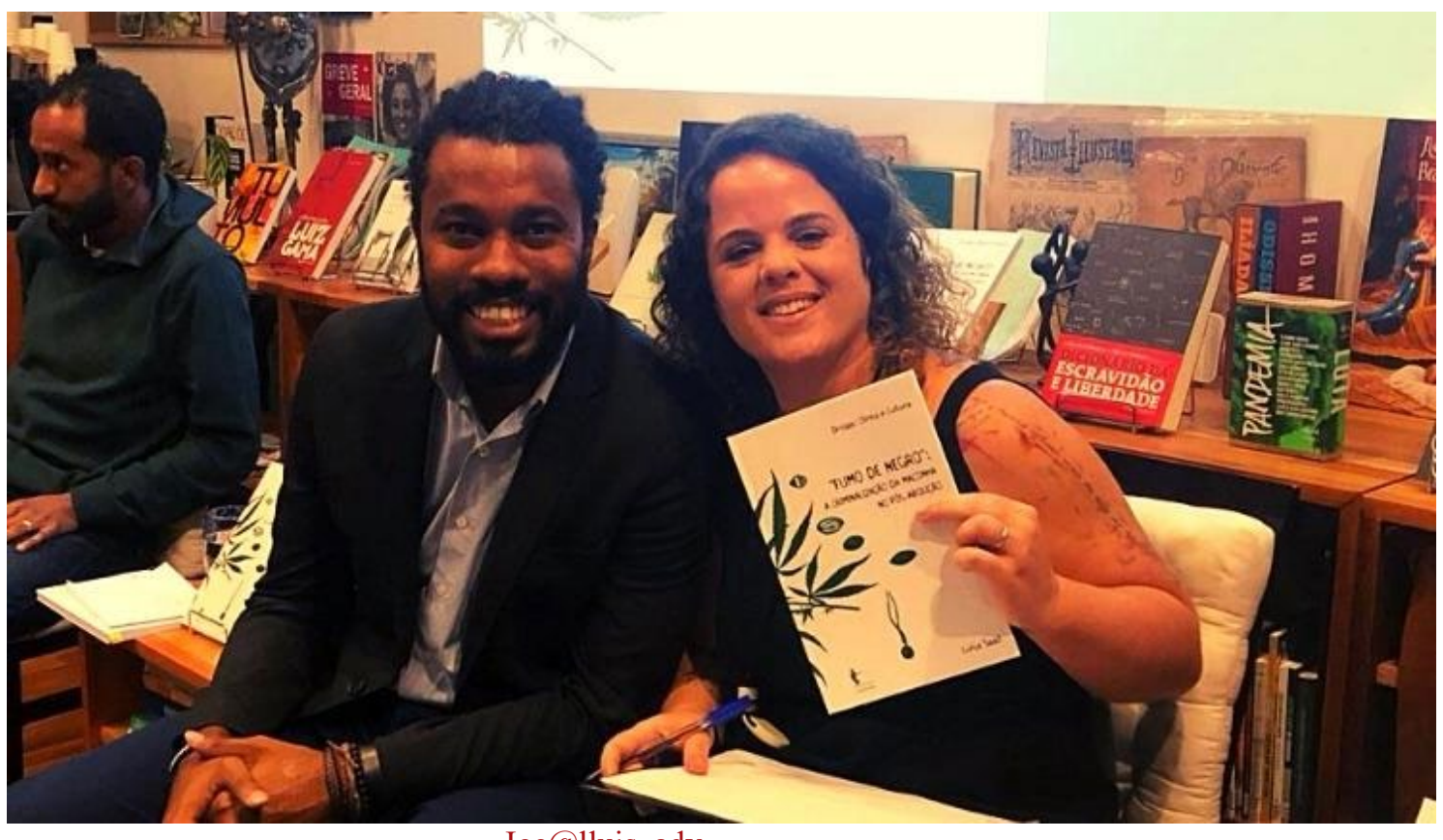

Joe@1luis_adv

Resultado de dissertação de mestrado defendida em 2013 por Luiza Saad, no programa de pós-graduação em História Social da Universidade Federal da Bahia (UFBA), o livro "Fumo de Negro": a criminalização da maconha no pós-abolição, publicado em 2019, investigou como se estabeleceu o discurso de criminalização da maconha que fundamentou a primeira lei de proibição dessa planta, em 1932, mas, que passou a inundar o imaginário social e constituir um discurso contra a maconha. 


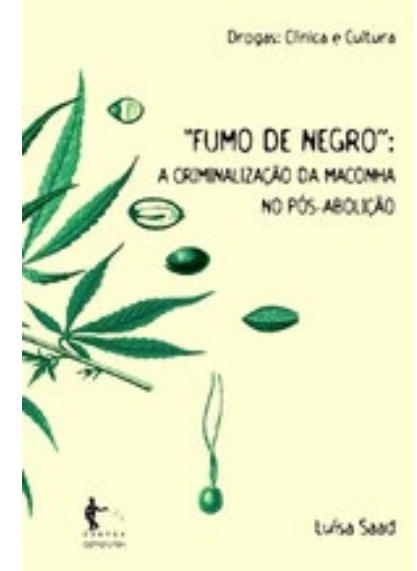

Essa problemática se estrutura a partir de uma revisão historiográfica que remonta à aproximação das ciências humanas em relação às drogas, movimento que, no Brasil, se caracterizou partir dos anos 1980. A autora parte de pesquisadores como Luiz Mott para reafirmar a tese de que não existe uma história da cannabis no Brasil. Embora não retrate uma história global dessa planta, ela contribui para a compreensão de um dos principais marcos desse processo: a mudança de tratamento em relação ao tema. Desta forma, é possível afirmar que o livro funciona como obra seminal para outras investigações, na medida em que incita a necessidade de atender outros recortes temporais.

Para responder seu questionamento, a autora se propôs a analisar documentos resultantes de conferências nacionais e internacionais, teses de médicos e autoridades sanitaristas e jornais entre 1890 e 1932, escolhas que vejo como acertadas na obra, pois permite o leitor observar com clareza onde e como o discurso de criminalização sobre a maconha se desenvolvia, em que círculos sociais transitava e que estratégias envolviam sua reprodução.

A obra se estrutura a partir de três capítulos: "Rodrigues Dória: a chama da proibição da maconha no Brasil"; "A danação da "erva maravilhosa" e "A maconha nos cultos afrobrasileiros." Os capítulos são antecedidos por um breve histórico em que a autora demonstra a íntima relação da maconha com a história da colonização do Brasil, chegando a se configurar, em determinado momento, como uma atividade econômica desempenhada pela coroa[1], tornando-se ilegal apenas no século XIX, momento em que surgem as primeiras legislações incriminatórias desses atos, deixando claro como esses se associavam contra a cultura negra, ignorando, inclusive, estudos científicos que não endossavam essas ideias. Em outras palavras, tratava-se de um aparelhamento da ciência para atingir fins pré-dispostos, marcados pelo racismo.

No primeiro capítulo, intitulado "Rodrigues Dória: a chama da proibição da maconha no Brasil", a autora mapeou a vida desse agente social, principal figura por trás dos estudos/discursos que fundamentaram a constituição da ilegalidade. Ela o faz como forma de situar o lugar social de onde emerge o discurso, a saber, de um intelectual branco abastado, médico e político. Esse incorporaria saberes disciplinares em vias de institucionalização (médico e farmacêutico) e concepções racistas, fundamentais para o desenvolvimento de políticas eugênicas que defendiam intervenções na população como forma de atingir um ideal de civilização, evocando elementos biológicos como forma de explicar problemas sociais.

Foi a partir dessa chave que Dória se posicionou sobre questões relacionadas ao lugar dos vícios, das mulheres, e do trabalho como ferramentas ou atravanco à constituição de um projeto de nação excludente em sua essência. Tomando como ponto de partida essa mesma estrutura discursiva, os sucessores de Dória operaram, demonstrando a importância desse intelectual para o campo correlato.

O segundo capítulo, denominado de "A danação da erva maravilhosa", a autora discorre a respeito de como as teses de Dória passaram a ser incorporadas ao discurso de criminalização da maconha. O uso dessa planta, como parte da cultura negra, e outras práticas associadas a esse grupo passavam a ser vistos como degenerantes uma vez que resultavam de uma classe perigosa, podendo ser estendidos por todas as demais classes sociais, estando assim na contramão do progresso. Os vícios passavam por esse filtro, 
sendo considerados doenças sociais que se relacionavam a predisposições biológicas, entretanto, quando associados às classes populares, eram apresentados de maneira mais enfática, podendo levar a quadros de dependência e, por sua vez, à violência.

Nesse capítulo, a autora demonstra os lugares onde os saberes especializados a respeito da maconha eram produzidos e circulavam. Tal processo se dava a partir da constituição de um saber médico que visava o monopólio sobre as patologias, substâncias e, também, sobre a cura. Configurava-se, assim, a constituição de uma autoridade social capaz de hierarquizar os vícios e de apresentar os que mais eram um risco ao modelo de sociedade e civilização que recortava as classes brancas desse país, a saber, os vinculados aos pobres e negros.

A institucionalização desse discurso se deu mediante a constituição de instituições locais e eventos internacionais, demonstrando que não era uma questão apenas do Brasil, mas que havia toda uma interlocução internacional que buscava estabelecer o controle e a moralização dessas substâncias e dos que dela faziam uso. No caso da maconha, os discursos estabelecidos se sustentavam em argumentos contraditórios e sem respaldo, ignorando qualquer estudo que não endossasse suas teorias racialistas.

O outro espaço de trânsito desse discurso analisado pela autora são os jornais os quais só passaram a apresentar notícias a respeito da maconha pouco antes da criminalização, na medida em que foram paulatinamente ocupados por detentores do saber médico, apresentando informações sobre a origem - sempre ligada aos africanos - dados de uso e a aproximação da maconha a outras drogas, como a cocaína e o ópio, que funcionavam como elementos moralizantes dessas práticas. Tais informações careciam de comprovações científicas, mas ganhavam foro de verdade a partir de seus interlocutores e dessa mídia, constituindo-se como ferramenta de intervenção social que prepararia o terreno para a proibição que se desenrolaria por meio das transformações que se instituíram com a revolução de 1930, mudando as perspectivas do Estado de liberais para autoritárias, caminhando para controles sociais mais intensos.

O terceiro capítulo, "A maconha nos cultos afro-brasileiros", demonstra como a proibição contribuiu para um processo de dessacralização do uso da maconha, envolvendo forças políticas, religiosas, econômicas e morais, atribuindo-lhe um uso secular que passava a ser justificado em si mesmo. Esse processo colocava na mira dos racistas os cultos africanos e afro-brasileiros que se associavam a essa substância, culminando com a desconfiguração do uso religioso dessa planta pelos seus próprios praticantes, que passaram a rejeitá-la. Tal processo teria se constituído, para a autora, a partir de dois conceitos centrais que circularam nos jornais diários e os textos legais, fetichismo e feitiço, elaborados pelas elites brancas para desqualificar a cultura africana e afro-brasileira a partir de um processo de homogeneização de diferentes práticas de cura e religiosidade, entendidas como oposição ao processo civilizatório.

Saddi conclui afirmando que, no Brasil, institucionalizou-se uma forma de perseguição das manifestações culturais associadas aos negros pós-abolição, tendo como argumento o combate a tais práticas como forma de cura social, estando a maconha entre elas. Esse combate tinha a sua frente os médicos, seus saberes e o Estado e, como pano de fundo, a tentativa de impedir a implementação de uma cidadania a essas populações, como reflexo do passado escravagista.

Essa obra pode ser vista como desenrolar das reflexões da autora desenvolvidas ainda durante a graduação, que já problematizavam o racismo científico. Esse livro proporciona ao leitor questionar os critérios de objetividade da própria ciência assim como compreender o processo de constituição de outros tipos de racismo, dentre eles, os 
institucionais, os quais se desenrolam a partir dos próprios aparatos estatais. Foi a ciência aparelhada em favor do racismo que levou à criminalização da maconha, sua desconfiguração como objeto do sagrado e à perseguição a práticas próprias dos negros no pós-abolição, mas que atingem nossa sociedade até hoje.

O que se vê nessa produção é a apresentação de um saber histórico que atua para a desmistificação da temática da maconha, a partir do desvelamento das estruturas que a constrangeram e as práticas a ela associadas. Tratar desse tema por meio dessa ciência também autoriza refletir a respeito de sua função social diante dos problemas do tempo presente, oferecendo um significado que ultrapassa a ideia de história como narração do passado: a de orientadora das ações frente ao presente.

A obra corrobora também para a ruptura de uma perspectiva interpretativa que exclui os negros e indígenas brasileiros dos diversos usos e resistências que foram estabelecidos a partir da maconha. Essa perspectiva a que a narrativa de Saad se opõe, aponta o uso de maconha, no Brasil, como resultado da importação de uma prática estadunidense por uma classe média brasileira branca que se identificava com os movimentos de contracultura e contestação durante a Ditadura Civil Militar brasileira. Essa narrativa não apenas nega o papel tradicional dessas comunidades em sua relação com os diversos usos da maconha, como traz para os grupos brancos o protagonismo relativo a essas práticas, desvelando apenas o uso recreativo que demarcaria a subversão.

A presente obra também autoriza refletir a respeito da constituição histórica de uma estrutura argumentativa que tem sido utilizada até nossos dias, originária de discursos médicos pouco objetivos, como forma de recriminar os mesmos grupos subalternos, tendo a maconha como indutora de suas práticas que culminam com a violência e criminalidade. Tal fato pode ser facilmente constatado nos telejornais sensacionalistas que formam a grade de programação da televisão aberta no Brasil. Longe de ser objetiva, a criminalização da maconha obedece a interesses que se desenrolam a partir de uma perspectiva racista.

Pensar a constituição histórica dessas elaborações mentais autoriza a desmistificação da ideia de objetividade jurídica e médica, elencando, assim, os seus graus de subjetividade e as relações que guardam devidamente com aqueles que ocupam seus espaços. O livro tem, portanto, esse mérito de se constituir como objeto de autorreflexão da própria ciência a que está vinculado, revelando bastidores do aparelhamento da ciência. Nesse sentido, penso que a obra mobiliza o método científico como forma de identificar as próprias contradições que se desenrolam na produção do conhecimento, assim como ferramenta de desmistificação de temas tidos como non gratos por nossa sociedade. A maconha aparece como uma ínfima parte de um emaranhado de relações que se desenvolveram por meio dela e que até hoje a estruturam, mas que estão em movimento, graças a trabalhos como este. Ler o livro é uma forma de se (re)encontrar com a maconha, dessa vez, como objeto de cognição.

\section{Nota}

[1] A atividade em questão citada pela autora é a Real Feitoria do Linho Cânhamo, instalada pela Coroa Portuguesa em 1791, no Rio Grande do Sul

\footnotetext{
Sumário de “Fumo de Negro”: a criminalização da maconha no pós-abolição

- Prefácio

- Apresentação
} 
- Introdução

- Rodrigues Dória: a chama da proibição da maconha no Brasil

- Formação e vida política

- Os (des)caminhos para a degeneração

- Gênero: a diferenciação entre os sexos

- Drogas (ou venenos) e sua relação com o crime

- A danação da "erva maravilhosa"

- O vício como pai do atraso e destruidor da moral

- Vícios sociais elegantes (cocaína, éter, ópio e derivados)

- Um vício nada elegante: a maconha como herança da raça subjugada

- Da academia para o dia a dia: a maconha nas páginas do jornal

- Queimando tudo

- A maconha nos cultos afro-brasileiros

- A “erva sagrada” e sua importância na África

- O contexto brasileiro

- A maconha e o candomblé

- Religião e cura

- Fetiche e feitiço

- Conclusão

- Referências

- Fontes

\section{Baixar gratuitamente "Fumo negro": a criminalização da maconha no pós- abolição}

\section{Resenhista}

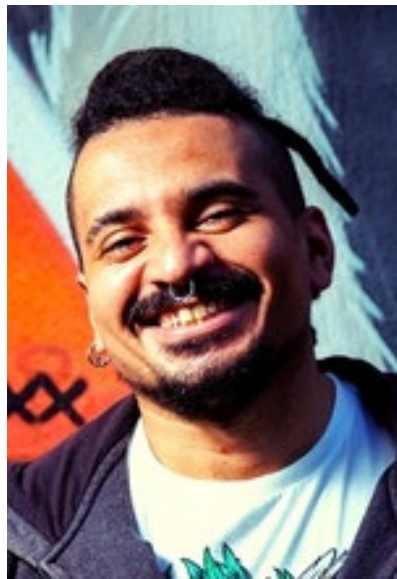

Jandson Bernardo Soares - Doutorando em História pela Universidade Federal do Rio Grande do Norte. Publicou, entre outros trabalhos, A institucionalização do livro didático no Brasil (2021) "História e Espaços do Ensino:

historiografia", PNLD e a busca por um livro didático ideal, A institucionalização do livro didático no Brasil e "Produzindo livros didáticos de História: prescrições e práticas - notas de uma pesquisa em andamento". Email: jandson_ze@hotmail.com.

\section{Referências desta resenha}

SAAD, Luísa. "Fumo de Negro": a criminalização da maconha no pós-abolição. Bahia: CETAD/EDUFBA. 2019. 160p. Resenha de: SOARES, Jandson Bernardo. À margem da lei. Crítica Historiográfica. Natal, v.2, n.3, jan./fev. 2022. Disponível em: https://www.criticahistoriografica.com.br/1838/

\section{Baixar esta resenha em PDF}


Outras resenhas sobre "Fumo de Negro": a criminalização da maconha no pósabolição

Daniela Ferrugem - Jlugar de livro[ - Jornal da Universidade - UFRGS (sd).

(C) - Os autores que publicam em Crítica Historiográfica concordam com a distribuição, remixagem, adaptação e criação a partir dos seus textos, mesmo para fins comerciais, desde que lhe sejam garantidos os devidos créditos pelas criações originais. (CC BY$\mathrm{SA})$ 